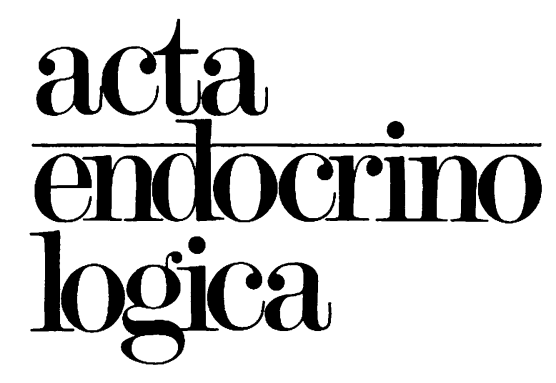




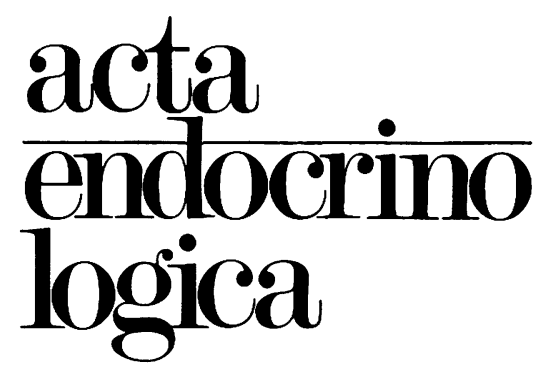

Volume 112

May - August 1986

Copenhagen

CHIEF EDITOR

C. BINDER

EDITORS

H. M. M. FREY

T. B. van WIMERSMA GREIDANUS

C. HAGEN

I. HUHTANIEMI

P. W. JUNGBLUT

TH. LEMARCHAND-BERAUD

J.-G. LJUNGGREN

CONSULTING EDITORS

C. HAMBURGER

J. STARUP 
Advisory Panel, page $\mathrm{V}$

Contents Vol. 112, page VII

Authors' Index, page XI

Subject Index, page XV
UniversitätsBibliothek

München

Printed in Denmark

by Bogtrykkeriet Forum

Copenhagen 
Prof. Asbjørn Aakvaag, Bergen, Norway. Prof. Kurt Ahrén, Göteborg, Sweden. Prof. Michael Apostolakis, Thessaloniki, Greece Dr. Jorgen Arends, Copenhagen, Denmark. Prof. Gustav Asboe-Hansen, Hellerup, Denmark. Dr. Michel L. Aubert, Genève, Switzerland Prof. G. M. Besser, London, UK. Prof. Dr. G. Bettendorf, Hamburg, FRG.

Prof. S. R. Bloom, London, UK

Prof. J. L. Van den Brande, Utrecht, The Netherlands. Prof. Dr. M. Breckwoldt, Freiburg, FRG.

Prof. Hans R. Brunner, Lausanne, Switzerland

Prof. Hans Bürgi, Solothurn, Switzerland.

Prof. Marc Bygdeman, Stockholm, Sweden.

Dr. Anne Grete Byskov, Copenhagen, Denmark.

Dr. Kevin Catt, Bethesda, USA.

Prof. Erol Cerasi, Jerusalem, Israel.

Prof. Tim Chard, London, UK.

Dr. William F. Crowley, Jr, Boston, USA.

Prof. Leslie J. DeGroot, Chicago, USA.

Prof. Fran ,cois Delange, Brussels, Belgium.

Dr. Paul Delost, Aubière, France.

Dr. Pierre A. Desaulles, Basel, Switzerland.

Prof. Dr. G. Dhom, Homburg-Saar, FRG.

Prof. Dr. E. J. Dorhout Mees, Utrecht, The Netherlands.

Dr. John-Fredrik Dymling, Malmö. Sweden.

Prof. Kristen B. Eik-Nes, Trondheim, Norway.

Dr. Walter Elger, Berlin, FRG.

Prof. Dr. F. Ellendorff, Neustadt, FRG

Dr. Ole Faber, Hørsholm, Denmark.

Dr. Ulla Feldt-Rasmussen, Copenhagen, Denmark.

Dr. Per Fernlund, Malmö, Sweden.

Prof. J. A. Fischer, Zürich, Switzerland.

Prof. H. Fleisch, Bern, Switzerland.

Prof. E.'Flückig'er, Básel, Switzerland.

Prof. Y. A. Fontaine, Paris, France.

Dr. Maguelone G. Forest, Lyon, France.

Prof. P. Franchimont, Liège, Belgium.

Prof. E. R. Froesch, Zürich, Switzerland.

Dr. Per Ivar Gaarder, Oslo, Norway.

Dr. Fulgencio Gomez, Lausanne, Switzerland.

Dr. Ariel Gordin, Helsinki, Finland.

Prof. Amirav Gordon, Jerusalem, Israel.

Prof. F. C. Greenwood, Honolulu, USA.

Prof. Kerstin Hall, Stockholm, Sweden.

Dr. Johan Halse, Oslo, Norway.

Prof. Dr. J. Hammerstein, Berlin, FRG.

Dr. Kristian F. Hanssen, Oslo, Norway.

Dr. Vidar Hansson, Oslo, Norway.

Dr. Egil Haug, Oslo, Norway.

Dr. H. N. Haugen, Oslo, Norway.
Prof. Chr. Hedinger, Zürich, Switzerland. Dr. Torbjörn Hillensjö, Göteborg, Sweden. Dr. Jens Juul Holst, Copenhagen, Denmark. Prof. Bernt Hökfelt, Malmö, Sweden. Prof. Howard S. Jacobs, London, UK. Prof. C. Jaffiol, Montpellier, France. Prof. Dr. Karl H. Jakobs, Heidelberg, FRG. Prof. Elof D. B. Johansson, Uppsala, Sweden. Prof. Alfred Jost, Paris, France.

Prof. Dr. Heinrich Karg, Freising-Weihenstephan, FRG.

Dr. Anders Karlsson, Uppsala, Sweden.

Dr. Knud W. Kastrup, Glostrup, Denmark. Prof. Dr. Rudolf Knuppen, Lübeck, FRG. Prof. Dr. J. Kracht, Giessen, FRG.

Prof. Dr. Michael Krieg, Bochum, FRG.

Prof. Dr. E. Kuss, München, FRG.

Dr. Claus Kühl, Klampenborg, Denmark. Prof. Dr. J. Köbberling, Göttingen, FRG.

Prof. Bror-Axel Lamberg, Helsinki, Finland.

Prof. Steven W. J. Lamberts, Rotterdam, The Netherlands. Prof. Jørgen Falck Larsen, Herlev, Denmark.

Dr. J. J. Legros, Liège, Belgium.

Prof. Marc L'Hermite, Bruxelles, Belgium.

Prof. Bruno Lunenfeld, Tel Hashomer, Israel.

Prof. Dr. Helmut Maske, München, FRG.

Prof. Dr. H. P. Meissner, Homburg-Saar, FRG.

Prof. Gabriela Morreale de Escobar, Madrid, Spain.

Prof. Jürg Müller, Zürich, Switzerland.

Prof. Dr. Friedmund Neumann, Berlin, FRG.

Prof. Maria I. New, New York, USA.

Dr. Karl Olof Nilsson, Malmö, Sweden.

Dr. Nils Norman, Oslo, Norway.

Prof. Dr. Wolfgang Oelkers, Berlin, FRG.

Dr. Risto Pelkonen, Kauniainen, Finland.

Prof. Andrea Prader, Zürich, Switzerland.

Prof. Dr. Hans-Jürgen Quabbe, Berlin, FRG.

Prof. Govind S. Rao, Bonn-Venusberg, FRG.

Prof. G. P. van Rees, Leiden, The Netherlands.

Prof. Jens F. Rehfeld, Copenhagen, Denmark.

Prof. Dr. Horst Schleusener, Berlin, FRG.

Prof. Dr. Helmuth Schmidt, Wiesbaden, FRG.

Dr. Gerard A. Schuiling, Groningen, The Netherlands.

Dr. Nancy B. Schwartz, Chicago, USA.

Prof. Dr. H. U. Schweikert, Bonn, FRG.

Dr. K. Siersbæk-Nielsen, Copenhagen, Denmark.

Prof. Niels Erik Skakkebæk, Hvidovre, Denmark.

Prof. Dr. P. G. Smelik, Amsterdam, The Netherlands.

Dr. Johan A. Sundsfjord, Tromsö, Norway.

Prof. Dr. D. F. Swaab, Amsterdam, The Netherlands.

Prof. Dr. H.-D. Taubert, Frankfurt/M, FRG.

Prof. J. H. H. Thijssen, Utrecht, The Netherlands. 
Prof. Dr. Helmut Thomas, Ulm, FRG.

Prof. Niels A. Thorn, Copenhagen, Denmark. Dr. George Tolis, Athens, Greece.

Prof. Olav Trygstad, Oslo, Norway.

Dr. W. M. G. Tunbridge, Newcastle upon Tyne, UK Prof. Michel B. Vallotton, Genève, Switzerland. Prof. Tapani Vanha-Perttula, Kuopio, Finland. Dr. J. van der Vies, Oss, The Netherlands. Dr. Hans Vilhardt, Copenhagen, Denmark. Prof. Dr. H. K. A. Visser, Rotterdam, The Netherlands. Prof. Dr. K. D. Voigt, Hamburg, FRG.

Prof. Peter Wahlberg, Mariehamn, Finland.
Dr. Jørgen Warberg, Copenhagen, Denmark. Dr. Jørgen Weeke, Århus, Denmark. Prof. Dr. Klaus von Werder, München, FRG. Prof. E. D. Williams, Cardiff, UK.

Prof. Charles B. Wilson, San Francisco, USA. Prof. Milo Zachmann, Zürich, Switzerland. Prof. Jürgen Zapf, Zürich, Switzerland. Prof. G. H. Zeilmaker, Rotterdam, The Netherlands. Prof. Uriel Zor, Rehovot, Israel.

Dr. Klaus Ølgaard, Copenhagen, Denmark. Prof. Hans Ørskov, Århus, Denmark.

Prof. Ivar Øye, Oslo, Nonway. 


\section{Hypothalamus}

Gayo L, Bonet B, Herranz A S, Iglesias R, Toro M J \& Montoya E: Postnatal development of brain TRH, serum TSH and thyroid hormones in the male and female rat $\ldots . . . \ldots \ldots \ldots .$.

Genazzani A R, Petraglia F, Sinforiani E, Brambilla F, Facchinetti F \& Nappi G: Dysregulation of plasma pro-opiomelanocortin-related peptides in neurotic depression ...................

Kemppainen R J, Filer D V, Sartin J L \& Reed R B: Ovine corticotrophin-releasing factor in dogs: dose-response relationships and effects of dexa-

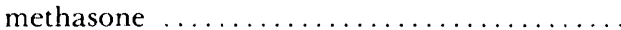

Lam K S L, Wang C, Ma J T C, Leung S P \& Yeung $R$ T T: Hypothalamic defects in two adult patients with septo-optic dysplasia $\ldots \ldots \ldots \ldots . . .305$

YoungLai E V, Pang S F \& Brown G M: Effects of different photoperiods on circulating levels of melatonin and $\mathrm{N}$-acetylserotonin in the female rabbit

\section{Pituitary}

Bakiri F, Riondel A M, Benmiloud M \& Vallotton M B: Aldosterone in panhypopitutarism: dynamic studies and therapeutic effects in Sheehan's syndrome ......................... 329

Brabant G, Ranft U, Ocran K, Hesch R D \& von zur Mühlen A: Thyrotropin - an episodically secreted hormone.

Brambilla F, Petraglia F, Facchinetti F \& Genazzani A R: Abnormal beta-endorphin and beta-lipotropin responses to TRH and LRH administration in primary and secondary affective disorders $\ldots \ldots \ldots \ldots \ldots \ldots \ldots \ldots \ldots . \ldots . \ldots . \ldots 4$

Bussien J P, Gaillard R C, Nussberger J, Waeber B, Hofbauer K G, Turnill D, Brögger R \& Brunner H R: Haemodynamic role of vasopressin released during Finnish sauna ............. 166

Degerblad M, Rähn T, Bergstrand G \& Thorén M: Long-term results of stereotactic radiosurgery to the pituitary gland in Cushing's disease ...... 310
Dickstein G, Lahav M \& Orr Z S: Single-dose metyrapone test at $06.00 \mathrm{~h}$ : an accurate method for assessment of pituitary-adrenal reserve .....

Escobar D C, Vicentini L M, Ghigo E, Ciccarelli E, Usellini L, Capella C \& Cocchi D: Growth hormone-releasing factor does not stimulate phosphoinositides breakdown in primary cultures of rat and human pituitary cells ............. 345

Ghigo E, Ciccarelli E, Bianchi S D, Gatti G, Molinatti $G$ M, Massara $F$, Müller E E \& Camanni $F$ : Comparison between pituitary computed tomographic findings and tests of hypothalamo-pituitary function in 72 patients with hyperprolactin-

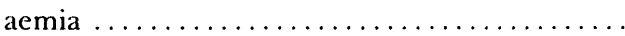

Gilna P \& Martin F: The effect of oestriol and tamoxifen on oestradiol induced prolactin secretion in anaesthetised rats ..................

Goodyer C G, Marcovitz S, Hardy J, Lefebvre Y, Guyda H J \& Posner B I: Effect of insulin-like growth factors on human foetal, adult normal and tumour pituitary function in tissue culture..

Haller H, Hensen J, Bähr V \& Oelkers W: Effects of angiotensin II infusion on the early morning surge of ACTH and on o-CRH-provoked ACTH secretion in normal man ............... 150

Leiba S, Shindel B, Weinberger I, Fuchs J, Rotenberg Z, Mor C \& Kaufman H: Cushing's disease coexisting with a single macronodule simulating adenoma of the adrenal cortex ............ 323

Lever E G, Butler J, Moore P, Cox T C S \& Maccabe J J: Infarction of a growth hormonesecreting macroadenoma during a TRH test . ... 172

Losa M, Huss R, König A, Müller $\mathrm{O} A$ \& von Werder $\mathrm{K}$ : Theophylline blunts the $\mathrm{GH}$-response to growth hormone releasing hormone in normal subjects .................... 473

Lundin S, Ákerlund M, Fagerström P-O, Hauksson A \& Melin P: Pharmacokinetics in the human of a new synthetic vasopressin and oxytocin uterine antagonist ................... 465

Milenković L, Bogić L \& Martinović J V: Effects of oestradiol and progesterone on stress-induced secretion of prolactin in ovariectomized and/or adrenalectomized female rats 
Moses N, Goldberg V, Gutman R \& Cácamo D: Combined FSH and $\mathrm{LH}$ secreting pituitary adenoma in a young fertile woman without primary gonadal failure .................

Roti E, Robuschi G, Alboni A, d'Amato L, Montermini M, Gardini E, Salvi M, Borciani E, Dall'Aglio E, Bisi S, Zammarchi G, Lasagni R, Gnudi A \& Braverman L E: Human foetal prolactin but not thyrotropin secretion is decreased by bromo-

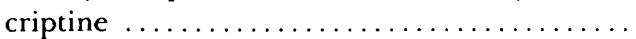

Schopohl J, Hauer A, Kaliebe T, Stalla G K, von Werder $\mathrm{K}$ \& Müller $\mathrm{O} \mathrm{A}$ : Repetitive and continuous administration of human corticotropin releasing factor to human subjects ........ 157

Swartz C M, Wahby V S \& Vacha R: Characterization of the pituitary response in the TRH test by

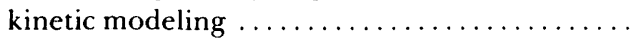

Terakawa N, Shimizu I, Aono T, Tanizawa O \& Matsumoto $\mathrm{K}$ : Dexamethasone inhibits the effects of oestrogen on the pituitary gland in rats . . van 't Verlaat J W, Croughs $\mathrm{R} J \mathrm{M}$, Hendriks $\mathrm{M} J$, Bosma N J, Nortier J W R \& Thijssen J H H: Bromocriptine treatment of prolactin secreting macroadenomas: a radiological, ophthalmological and endocrinological study .......... 48

Wide $\mathrm{L}$ : The regulation of metabolic clearance rate of human $\mathrm{FSH}$ in mice by variation of the molecular structure of the hormone ....... 336

Wogensen L \& Warberg J : Effect of prostaglandin $\mathrm{D}_{2}$ on the release of luteinizing hormone and prolactin in castrated and intact male rats .... 180

\section{Thyroid}

Benker G, Rasche H, Olbricht Th, Meinhold H, Teuber J \& Reinwein D: Response of total and 'free' thyroid hormones and diiodotyrosine to bovine TSH in subclinical hypothyroidism . . . . . 509

Boye $\mathrm{N}$ : Thyroxine monodeiodination in normal human kidney tissue in vitro . . . . . . . 536

del Carmen Arqueros M, Niepomniszcze H \& Moreno J: Thyroid glands in patients with Graves' disease are sources of thyrotropin-binding inhibitory (TBI) activity

Gutekunst R, Smolarek H, Hasenpusch U, Stubbe P, Friedrich H-J, Wood W G \& Scriba P C: Goitre epidemiology: thyroid volume, iodine excretion, thyroglobulin and thyrotropin in Germany and Sweden ........................ 494

Haraguchi $K$, Endo $T$ \& Onaya $T$ : Effects of phorbol esters on protein phosphorylation and free $T_{3}$ release by mouse thyroid lobes ...... 217

litaka M, Tanikawa T, Sakatsume Y, Yanagisawa M, Hara Y \& Ishii J : Interference with thyrotropin receptor antibody determination by a spuriously occurring anti-bovine TSH antibody ......
I keda T, Ito Y, Murakami I, Mokuda O, Tominaga $M$ \& Mashiba $\mathrm{H}$ : Conversion of $\mathrm{T}_{4}$ to $\mathrm{T}_{3}$ in perfused liver of rats with carbontetrachlorideinduced liver injury $\ldots \ldots \ldots \ldots \ldots \ldots \ldots$

Imamura M, Aoki N, Saito T, Ohno Y, Maruyama $\mathrm{Y}$, Yamaguchi J \& Yamamoto $\mathrm{T}$ : Inhibitory effects of antithyroid drugs on oxygen radical formation in human neutrophils ......... 21

Morita S, Izumi $M$ \& Nagataki S: Interactions between TSH binding inhibiting - and adenylate cyclase stimulating - antibodies in Graves' disease .................... 517

Perrild H, Hansen J M, Arnung K, Olsen P Z \& Danielsen $\mathrm{U}$ : Intellectual impairment after hyperthyroidism ................ 185

Potter B J, McIntosh G H, Mano M T, Baghurst P A, Chavadej J, Hua C H, Cragg B G \& Hetzel B $S$ : The effect of maternal thyroidectomy prior to conception on foetal brain development in

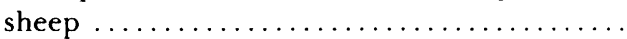

Ramsden D B \& Crossley D N: Serum concentrations of $3,5,3^{\prime}, 5^{\prime}$-tetraiodothyroacetate $\left(\mathrm{T}_{4} \mathrm{~A}\right)$ in subjects with hypo-, hyper-and euthyroidism . . 192

Schatz H, Pschierer-Berg K, Nickel J-A, Bär R, Müller F, Bretzel R G, Müller H \& Stracke H: Assay for thyroid growth stimulating immunoglobulins: stimulation of $\left[{ }^{3} \mathrm{H}\right]$ thymidine incorporation into isolated thyroid follicles by TSH, $\mathrm{EGF}$, and immunoglobulins from goitrous patients in an iodine-deficient region ......... 523

Thomson J A, Wilson $\mathrm{R}$ \& Walker I D: The development of thyrotoxicosis (Graves' disease) during immunosuppression for autoimmune haemolytic anaemia .............. 531

Wadeleux P A \& Winand R J: Thyroid growth modulating factors in the sera of patients with simple non-toxic goitre . . . . . . . . . . . . . 502

van der Gaag R D, von Blomberg-van der Flier $M$, van de Plassche-Boers E, Kokjé-Kleingeld $M$ \& Drexhage $\mathrm{H} \mathrm{A}$ : T-suppresor cell defects in euthyroid nonendemic goitre .............

Yamashita S, Izumi $M$ \& Nagataki $S$ : Specific stimulatory effects of Graves' IgG on the release of triiodothyronine from the patients' own thyroids .......................... 20

\section{Parathyroid}

Kristiansen J H, Brøchner-Mortensen J \& Pedersen $\mathrm{K} \mathrm{O}$ : Renal tubular reabsorption of calcium in familial hypocalciuric hypercalcaemia

\section{Pancreas}

Groop P-H, Groop L, Tötterman K J \& Fyhrquist $F$ : Effects of Acarbose on the relationship be- 
tween changes in GIP and insulin responses to meals in normal subjects . ........... 361

Gross R \& Mialhe P: Free fatty acids and pancreatic function in the duck ........... 100

Lamas L \& Jolin T: Intrathyroidal thyroglobulin in

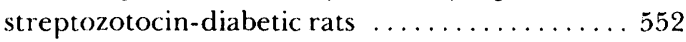

MacFarlane I A, Stafford S \& Wright A D: Circulating growth hormone forms in Type 1 diabetic subjects: comparison with normal subjects and acromegalics .................. 547

Martino E, Grasso S, Bambini G, Pardo G, Vitti P, Aghini-Lombardi F \& Pinchera A: Ontogenetic development of pancreatic thyrotropin-releasing hormone in human foetuses and in infants . 372

Svenningsen A, Dyrberg T, Markholst H, Binder C \& Lernmark $\AA$ : Insulin release and pancreatic insulin is reduced in young prediabetic BB rats . 367

Yki-Järvinen $\mathrm{H}$, Helve E \& Koivisto V A : Relationship between oral glucose tolerance and insulin sensitivity in healthy man and type 1 diabetic patients

\section{Liver}

Cavallo-Perin P, Bruno A, Nuccio P, Dall'omo A M, Fronda G R, Avagnina P, Molino G, Bozzo C \& Pagano $G$ : Insulin resistance in human liver cirrhosis is not modified by porto-systemic surgical shunt ................... 377

de Vries C P \& van der Veen E A : Characterization of insulin-binding to the hepatoma cell line H35 ..................... 559

Okahata H, Nishi Y, Muraki K, Sumii K, Miyachi Y \& Ueda K: Development of gastric somatostatinlike immunoreactivity in response to corticosterone acetate and dietary changes in young rats .. 383

\section{Gastro-intestinal tract}

Bailey C J, Flatt P R, Kwasowski P, Powell C J \& Marks $\mathrm{V}$ : Immunoreactive gastric inhibitory polypeptide and $\mathrm{K}$ cell hyperplasia in obese hyperglycaemic (ob/ob) mice fed high fat and high carbohydrate cafeteria diets

\section{Adrenals}

Dupouy J P \& Chatelain A : Effects of progesterone induced postmaturity on CBG and pituitaryadrenal activities in the rat foetus ......... 396

Kenyon C J, Clark S A, Hannah J A M, Holloway C D, Ingram M C, Lindop G, Towrie A \& Ball S G: The relative importance of glucocorticoids and mineralocorticoids in the development of adrenal regeneration hypertension in rats
Magalhães M C, Vitor A B \& Magalhães $M$ M: Effects of ACTH on RNA synthesis and migration in the adrenal cortex cells of the young rat, as shown by radioautography ........... 114

Müller J: Divergent effects of dietary chloride restriction on aldosterone biosynthesis and the renin-angiotensin system in rats ......... 105

Nakano K, Suzuki S, Chanho O \& Yamashita K: Possible role of glucocorticoids in a complementacti-vated state induced by cobra venom factor in rats

Tourniaire J, Chalendar D, Rebattu B, Fevre-Montange M, Bajard L, Mazenod B, Dechaud H, Abou Samra A B \& van Cauter E: The 24-h cortisol secretory pattern in Cushing's syndrome ..................... 230

\section{Ovaries}

Gross D J, Landau H, Kohn G, Farkas A, Elrayyes E, El-Shawwa R, Lasch E E \& Rösler A: Male pseudohermaphroditism due to $17 \beta$-hydroxysteroid dehydrogenase deficiency: gender reassignment in early infancy . . . . . . . . . 238

Hooper S B, Walker D W \& Thorburn G D: Cannulation of the utero-ovarian vein in intact ewes: hormone concentrations and blood gas levels during the oestrous cycle and early pregnancy .......................... 253

Robba C, Rebuffat P, Mazzocchi G \& Nussdorfer G $G$ : Long-term trophic action of $\alpha$-melanocytestimulating hormone on the zona glomerulosa of the rat adrenal cortex ................. 404

Rosberg S, Norjavaara E, Sender Baum M \& Khan $\mathrm{I}$ : Adenylate cyclase activity in rat corpora lutea evidence for a rapid development of the regulatory $\mathrm{N}_{\mathrm{s} \text {-protein } \ldots \ldots \ldots \ldots \ldots \ldots \ldots \ldots \ldots \ldots \ldots \ldots \ldots \ldots \ldots \ldots}$

Sender-Baum M G \& Ahrén K E B: Effects of forskolin, luteinizing hormone and prostaglan$\operatorname{din} \mathrm{F}_{2 \alpha}$ on isolated rat corpora lutea .......571 van der Schoot P \& de Greef W J: Development of ovarian follicles during lactation in rats . . . . 247

Weusten J J A M, Blankenstein M A, GmeligMeyling $\mathrm{F} \mathrm{H}$ J, Schuurman $\mathrm{H}$ J, Kater L \& Thijssen $\mathrm{J} \mathrm{H} \mathrm{H}$ : Presence of oestrogen receptors in human blood mononuclear cells and thymocytes

\section{Uterus}

Papapetrou P D \& Nicopoulou S Ch: The origin of a human chorionic gonadotropin $\beta$-subunit-core fragment excreted in the urine of patients with cancer ................... 415 


\section{Pregnancy}

Buch I, Hornnes P J \& Kühl C: Glucose tolerance in early pregnancy .................. 263

Honjo H, Kitawaki J, Itoh M, Yasuda J, Yamamoto T, Yamamoto T, Okada H, Ohkubo T \& Nambara $\mathrm{T}$ : Serum and urinary oestrone sulphate in pregnancy and delivery measured by a direct radioimmunoassay .................... 423

Julkunen M: Human decidua synthesizes placental protein 14 (PP14) in vitro .............. 271

Koyama K, Toda K, Kuriyama D \& Isojima S: Affinity to lectin, biological and immunological characteristics of human chorionic gonadotropins from pregnant women and trophoblastic tumour patients ................ 579

Sairam M R, Kato K, Mukhopadhyay A K \& Bohnet H G: Preparation and properties of human chorionic gonadotropin antagonist for biological studies: antifertility effects in the female rat ......................... 586

Stegner H, Fischer K, Pahnke V G, Kitschke H J \& Commentz J C: There is evidence that amniotic fluid arginine vasopressin is a marker for foetal stress in rhesus erythroblastosis . . . . . . . . 267

\section{Testes}

Garza-Flores J, Vilchis F, Garcia G A, Menjivar M \& Pérez-Palacios G: A-ring reduction enhances the antigonadotropic potency of norethisterone . 278

Lemarchand-Béraud Th, Jaussan V \& Zürich M G: Dose and time effects of treatment with low doses of a LRH agonist on testicular axis and accessory sex organs in rats .............. 595

Vawda A I \& Davies A G: Effects of cisplatin on the mouse testis

Vihko K K, Toppari J, Saksela O, Suominen J J O \& Parvinen $\mathrm{M}$ : Testicular plasminogen activators during postnatal development in the rat ... 431

\section{Miscellaneous}

Bigazzi M, Del Mese A, Petrucci F, Casali R \& Novelli G P: The local administration of relaxin induces changes in the microcirculation of the rat mesocaecum ....................... 296

Caufriez A, Golstein J, Tadjerouni A, Bosson D, Cantraine F, Robyn C \& Copinschi G: Modulation of immunoreactive somatomedin-C levels by sex steroids ..................... 284

Hammond G L \& Langley M S: Identification and measurement of sex hormone binding globulin (SHBG) and corticosteroid binding globulin (CBG) in human saliva .

Lakshmanan J: Neonatal hyperthyroidism causes impairment in submandibular gland-nerve growth factor (SMG-NGF) ontogeny in mice ... 138

Lakshmanan J \& Perheentupa J: Reduced urinary epidermal growth factor levels in Snell dwarf mutant mice ........................ 461

Lundin $\mathrm{S} \&$ Vilhardt $\mathrm{H}$ : Absorption of 1-deamino8-D-arginine vasopressin from different regions of the gastrointestinal tract in rabbits ......... 457

MacFarlane M \& Skett P:Time course of the effect of streptozotocin on serum concentration of glucose and triglycerides and on hepatic drug metabolism in the male rat ................. 300

Minetti C A S A, Valle L B S, Fava-De-Moraes F, Romaldini J H \& Oliveira-Filho R M: Ontogenesis of androgen receptors in the mouse submandibular gland: correlation with the developmental profiles of circulating thyroid and testicular hormones .......................... 290

Myking O, Aakvaag A \& Ohm O J: Splanchnic extraction of oestrone and oestradiol and production of oestrone sulphate in man ......... 442

Takano K, Hizuka N \& Shizume K: Treatment of Turner's syndrome with methionyl human growth hormone for six months ........... 130

Zondek T, Mansfield M D, Attree S L \& Zondek I. $\mathrm{H}$ : Hormone levels in the foetal and neonatal prostate ......................... 447 
Aakvaag A, 442

Abou Samra A B, 230

Aghini-Lombardi F, 372

Ahrén K E B, 571

Alboni A, 35

Aoki N, 210

Aono T, 64

Arnung K, 185

Attree S L, 447

Avagnina $P, 377$

Baghurst P A, 93

Bailey C J 224

Bajard L, 230

Bakiri F, 329

Ball S G, 389

Bambini $G, 372$

Benker G, 509

Benmiloud M, 329

Bergstrand G, 310

Bianchi S D, 20

Bigazzi M, 296

Binder C, 367

Bisi S, 35

Blankenstein M A, 409

Blomberg-van der Flier $\mathrm{M}$ von, 83

Bogic L, 79

Bohnet H G, 586

Bonet $\mathrm{B}, 7$

Borciani E, 35

Bosma N J, 487

Bosson D, 284

Boye N, 536

Bozzo C, 377

Brabrant $G, 315$

Brambilla F, 1, 481

Braverman L E, 35

Bretzel R G, 523

Brown G M, 145

Brunner H R, 166

Bruno A, 377

Brøchner-Mortensen J, 541

Brögger R, 166

Buch I, 263

Bussien J P, 166

Butler J, 172

Bähr V, 150

Bär R, 523
Cácamo D, 58

Camanni F, 20

Cantraine F, 284

Capella C, 345

Carmen Arqueros M del, 351

Casali R, 296

Caufriez A, 284

Cauter E van, 230

Cavallo-Perin P, 377

Chalendar D 230

Chanho O, 122

Chatelain A, 396

ChavadejJ, 93

Ciccarelli E, 20, 345

Clark S A, 389

Cocchi D, 345

Commentz J C, 267

Copinschi G, 284

Cox T C S, 172

Cragg B G, 93

Crossley D N, 192

Croughs R J M, 487

Dall'Aglio E, 35

Dall'omo A M, 377

d'Amato L, 35

Danielsen U, 185

Davies A G, 436

Dechaud H, 230

Degerblad M, 310

Del Mese A, 296

Dickstein (, 28

Drexhage H A, 83

Dupouy J P, 396

Dyrberg T, 367

Elrayyes E, 238

El-Shawwa R, 238

Endo T, 217

Escobar D C, 345

Facchinetti F, 1, 481

Fagerström P-O, 465

Farkas A, 238

Fava-De-Moraes F, 290

Fevre-Montange M, 230

Filer D V, 12

Fischer K, 267
Flatt P R, 224

Friedrich H-J, 494

Fronda G R, 377

Fuchs J, 323

Fyhrquist F, 361

Gaag R D van der, 83

Gaillard R C, 166

García G A, 278

Gardini E, 35

Garza-Flores J, 278

Gatti G, 20

Gayo L, 7

Genazzani A R, 1, 481

Ghigo E, 20, 345

Gilna P, 71

Gmelig-Meyling F H J, 409

Gnudi A, 35

Goldberg V, 58

Golstein J, 284

Goodyer C G, 49

Grasso S, 372

Greef W J de, 247

Groop L, 361

Groop P-H, 361

Gross D J, 238

Gross R, 100

Gutekunst R, 494

Gutman R, 58

Guyda H J, 49

Haller $\mathrm{H}, 150$

Hammond G L, 603

Hannah J A M, 389

Hansen J M, 185

Hara Y, 197

Haraguchi K, 217

Hardy J, 49

Hasenpusch U, 494

Hauer A, 157

Hauksson A, 465

Helve E, 355

Hendriks M J, 487

Hensen J, 150

Herranz A S, 7

Hesch R D, 315

Hetzel B S, 93

Hizuka N, 130 
Hofbauer K G, 166

Holloway C D, 389

Honjo $\mathrm{H}, 423$

Hooper S B, 253

Hornnes P J, 263

Hua $\mathrm{C} \mathrm{H}, 93$

Huss R, 473

Iglesias R, 7

Iitaka M, 197

Ikeda T, 89

Imamura M 210

Ingram M C, 389

Ishii J, 197

Isojima S, 579

Ito $\mathrm{Y}, 89$

Itoh $\mathrm{M}, 423$

Izumi M, 204, 517

Jaussan $\mathrm{V}, 595$

Jolin T, 552

Julkunen M, 271

Kaliebe T, 157

Kater L, 409

Kato K, 586

Kaufman H, 323

Kemppainen R J, 12

Kenyon C J, 389

Khan I, 565

Kitawaki J, 423

Kitschke H J, 267

Kohn G, 238

Koivisto V A, 355

Kokjé-Kleingeld M, 83

Koyama K, 579

Kristiansen J H, 541

Kühl C, 263

Kuriyama D, 579

Kwasowski P, 224

König A, 473

Lahav M, 28

Lakshmanan J, 138, 461

Lam K S L, 305

Lamas L, 552

Landau $\mathrm{H}, 238$

Langley M S, 603

Lasagni $R, 35$

Lasch E E, 238

Lefebre $Y, 49$

Leiba S, 323

Lemarchand-Béraud Th, 595

Lernmark $\AA, 367$

Leung S P, 305

Lever E G, 172

Lindop G, 389
Losa M, 473

Lundin S, 457, 465

Ma J T C, 305

Maccabe J J, 172

MacFarlane I A, 547

MacFarlane M, 300

Magalhães M C, 114

Magalhães M M, 114

Mano M T, 93

Mansfield M D, 447

Marcovitz S, 49

Markholst H, 367

Marks V, 224

Martin F, 71

Martino E, 372

Martinović J V, 79

Maruyama Y, 210

Mashiba H, 89

Massara F, 20

Matsumoto K, 64

Mazenod B, 230

Mazzocchi G, 404

McIntosh G H, 93

Meinhold H, 509

Melin P, 465

Menjivar M, 278

Mialhe P, 100

Milenković L, 79

Minetti C A S A, 290

Miyachi Y, 383

Mokuda O, 89

Molinatti G M, 20

Molino G, 377

Montermini M, 35

Montoya E, 7

Moore P, 172

Mor C, 323

Moreno J, 351

Morita S, 517

Moses N, 58

Mühlen A von zur, 315

Müller E E, 20

Müller F, 523

Müller H, 523

Müller J, 105

Müller O A, 157, 473

Mukhopadhyay A K, 586

Murakami I, 89

Muraki K, 383

Myking O, 442

Nagataki S, 204, 517

Nakano K, 122

Nambara T, 423

Nappi G, 1

Nickel J-A, 523
Nicopoulou S Ch, 415

Niepomniszcze $\mathrm{H}, 35 \mathrm{l}$

Nishi Y, 383

Norjavaara E, 565

Nortier J W R, 487

Novelli G P, 296

Nuccio P, 377

Nussberger J, 166

Nussdorfer G G, 404

Ocran K, 315

Oelkers W, 150

Ohkubo T, 423

Ohm O J, 442

Ohno Y, 210

Okada H, 423

Okahata H, 383

Olbricht Th, 509

Oliveira-Filho R M, 290

Olsen P Z, 185

Onaya T, 217

Orr Z S, 28

Pagano G, 377

Pahnke V G, 267

Pang S F, 145

Papapetrou P D, 415

Pardo G, 372

Parvinen M, 431

Pedersen K O, 541

Pérez-Palacios G, 278

Perheentupa J, 461

Perrild $\mathrm{H}, 185$

Petraglia F, 1, 481

Petrucci F, 296

Pinchera A, 372

Plassche-Boers E van de, 83

Posner B I, 49

Potter B J, 93

Powell C J, 224

Pschierer-Berg K, 523

Ramsden D B, 192

Ranft U, 315

Rasche H, 509

Rebattu B, 230

Rebuffat P, 404

Reed R B, 12

Reinwein D, 509

Riondel A M, 329

Robba C, 404

Robuschi G, 35

Robyn C, 284

Romaldini J H, 290

Rosberg S, 565

Rotenberg Z, 323

Roti E, 35 
Rähn T, 310

Rösler A, 238

Sairam M R, 586

Saito T, 210

Sakatsume Y, 197

Saksela $O, 431$

Salvi M, 35

Sartin J L, 12

Schatz H, 523

Schoot $\mathrm{P}$ van der, 247

Schopohl J, 157

Schuurman H J, 409

Scriba P C, 494

Sender Baum M G, 565, 571

Shimizu I, 64

Shindel B, 323

Schizume K, 130

Sinforiani E, 1

Skett $\mathrm{P}, 300$

Smolarek H, 494

Stafford S, 547

Stalla G K, 157

Stegner H, 267

Stracke H, 523

Stubbe P, 494

Sumii K, 383

Suominen J J O, 431

Suzuki S, 122

Svenningsen A, 367

Swartz C M, 43

Tadjerouni A, 284

Takano K, 130
Tanikawa T, 197

Tanizawa $\mathrm{O}, 64$

Terakawa N, 64

Teuber J, 509

Thijssen J H H, 409, 487

Thomson J A, 531

Thorburn G D, 253

Thorén M, 310

Toda K, 579

Tominaga M, 89

Toppari J, 431

Toro M J, 7

Tourniaire J, 230

Towrie A, 389

Turnill D, 166

Tötterman K J, 361

Ueda K, 383

Usellini L, 345

Vacha R, 43

Valle L B S, 290

Vallotton M B, 329

Vawda A I, 436

Veen E A van der, 559

Verlaat J W van't, 487

Vicentini L M, 345

Vihko K K, 431

Vilchis F, 278

Vilhardt $\mathrm{H}, 457$

Vitor A B, 114

Vitti P, 372

Vries C P de, 559
Wadeleux P A, 502

Waeber B, 166

Wahby V S, 43

Walker D W, 253

Walker I D, 531

Wang C, 305

Warberg J, 180

Weinberger I, 323

Werder K von, 157, 473

Weusten J J A M, 409

Wide L, 336

Wilson R, 531

Winand R J, 502

Wogensen L, 180

Wood W G, 494

Wright A D, 547

Yamaguchi J, 210

Yamamoto T, 210 ,

Yamamoto T, 423

Yamashita K, 122

Yamashita S, 204

Yanagisawa M, 197

Yasuda J, 423

Yeung R T T, 305

Yki-Järvinen $\mathrm{H}, 355$

YoungLai E V, 145

Zammarchi G, 35

Zondek L H, 447

Zondek T, 447

Zürich M G, 595

Åkerlund M, 465 



\section{ACARBOSE}

effects in the relationship between changes in GIP and insulin responses to meals in normal subjects, 361

\section{ACROMEGALY}

circulating growth hormone forms in acromegalic patients, 547

\section{ADAPTATION SYNDROME}

stress; effects of oestradiol and progesterone on stress-induced prolactin secretion in rats, 79

stress; foetal stress in rhesus erythroblastosis, 267

\section{ADENYLATE CYCLASE}

activity in rat corpora lutea, 565

\section{ADRENAL, CORTEX}

adrenal regeneration hypertension in rats, 389

effect of ACTH on RNA synthesis and migration in adrenocortical cells of rats, 114

effects of $\alpha$-MSH on zona glomerulosa in rats, 404 macronodule stimulating adenoma of the adrenal cortex coexisting with Cushing's disease, 323

pituitary-adrenal reserve; assessment by a single dose metyrapone test at $06.00 \mathrm{~h}, 28$

\section{ALDOSTERONE}

biosynthesis: divergent effects of chloride restriction on aldosterone biosynthesis and the renin-angiotensin system in rats, 105

in panhypopituitarism; dynamic studies and effect in Sheehan's syndrome, 329

\section{ANDROGENS}

in the foetal and neonatal prostate, 447

ontogenesis of androgen receptors in the mouse submandibular gland, 290

\section{ANGIOTENSIN}

divergent effects of chloride restriction on aldosterone biosynthesis and the renin-angiotensin system in rats, 105

effects of angiotensin II on the morning surge of ACTH and on o-CRF-provoked ACTH secretion in man, 150

\section{ANTIGONADOTROPINS}

A-ring reduction enhances the antigonadotropic potency of norethisterone, 278

\section{ANTIOESTROGENS}

tamoxifen; effect on oestradiol-induced Prl secretion in rats, 71

\section{ANTITHYROID COMPOUNDS}

inhibitory effects on oxygen radical formation in human neutrophils, 210

\section{BLOOD}

autoimmune haemolytic anaemia; development of Graves' disease during immunosuppression, 531

haemodynamic role of vasopressin released during Finnish sauna, 166

inhibitory effects of antithyroid compounds on oxygen radical formation in human neutrophils, 210

oestrogen receptors in human blood mononuclear cells, 409

BRAIN

effect of maternal thyroidectomy on foetal brain development in sheep, 93

intellectual impairment after hyperthyroidism, 185

\section{BROMOCRIPTINE}

human foetal Prl but not TSH secretion is decreased by bromocriptine, 35

treatment of Prl-secreting pituitary macroadenomas, 487

\section{CALCIUM}

renal tubular reabsorption of calcium in familial hypocalciuric hypercalcaemia, 541

\section{CANNULATION}

of the utero-ovarian vein in intact ewes, 253

\section{CARBONTETRACHLORIDE}

liver injury in rats; conversion of $T_{4}$ to $T_{3}$ in the perfused liver, 89 


\section{CHORIONIC GONADOTROPIN}

affinity to lectin, biological and immunological characteristics of hCG from pregnant women and trophoblactic tumour patients, 579

hCG antagonist; preparation and properties; antifertility effects in rats, 586

origin of a hCG $\beta$-subunit-core fragment excreted in the urine of patients with cancer, 415

\section{CISPLATIN}

effects on the mouse testis, 436

\section{COBRA VENOM}

role of glucocorticoids in a complement-activated state induced by cobra venom factor in rats, 122

\section{COMPLEMENT SYSTEM}

role of glucocorticoids in a complement-activated state induced by copra venom factor in rats, 122

\section{CORPUS LUTEUM}

adenylate cyclase activity in rat corpora lutea, 565 effects of forskolin, $\mathrm{LH}$ and prostaglandin $\mathrm{F}_{2} \alpha$ on isolated rat corpora lutea, 571

\section{CORTICOSTEROIDS}

corticosteroid binding globulin in human saliva, 603 relative importance of gluco- and mineralocorticoids in development of adrenal regeneration hypertension in rats, 389

role of glucocorticoids in a complement-activated state induced by copra venom factor in rats, 122

\section{CORTICOSTERONE}

effect of progesterone-induced postmaturity on CBG in the rat foetus, 396

\section{CORTICOTROPIN}

effect on RNA synthesis and migration in the adrenocortical cells of rats, 114

effects of angiotensin II on the morning surge of ACTH and on o-CRF-provoked ACTH secretion in man, 150

ovine ACTH-releasing factor in dogs; dose-response relationships and effects of dexamethasone, 12 repetitive and continuous administration of $h-C R F$ on ACTH secretion in human subjects, 157

\section{CORTISOL}

plasma level in patients with neurotic depression, 1 the 24-h cortisol secretory pattern in Cushing's syndrome, 230

\section{CUSHING'S SYNDROME}

Cushing's disease coexisting with a macronodule stimulating adenoma of the adrenal cortex, 323 stereotactic radiosurgery to the hypophysis in

Cushing's disease, 310

the 24-h cortisol secretory pattern in Cushing's syndrome, 230

\section{DECIDUA}

human decidua synthesizes placental protein 14 in vitro, 271

\section{DEXAMETHASONE}

effects on ovine CRF in dogs, 12

\section{DIABETES MELLITUS}

circulating growth hormone forms in type 1 diabetic subjects, 547

intrathyroidal thyroglobulin in

streptozotocin-diabetic rats, 552

relationship between OGT and insulin sensitivity in type 1 diabetes and in healthy man, 355

\section{DWARFISM}

reduced urinary epidermal growth factor levels in Snell dwarf mutant mice, 461

\section{ENDORPHIN}

abnormal $\beta$-endorphin responses to TRH and LRH in patients with affective disorders, 481

$\beta$-endorphin dysregulation in neurotic depression, 1

\section{ENZYMES}

an alpha-glucosidase inhibitor: Acarbose, 361

$17 \beta$-hydroxysteroid dehydrogenase deficiency; male pseudohermaphroditism, 238

$\mathrm{N}$-acetyl transferase; effects of photoperiods on melatonin and $\mathrm{N}$-acetyl-serotonin in rabbits, 145

\section{EPIDERMAL GROWTH FACTOR}

reduced urinary EGF levels in Snell dwarf mutant mice, 461

\section{ERYTHROBLASTOSIS}

amniotic vasopressin is likely to be a marker for foetal stress, 267

\section{FERTILITY}

antifertility effects of a hCG antagonist in female rats, 586

\section{FINNISH SAUNA}

haemodynamic role of vasopressin released during Finnish sauna, 166

\section{FOETAL ENDOCRINOLOGY}

effects of insulin-like growth factors on human foetal pituitary function in culture, 49 
effects of progesterone-induced postmaturity on CBG and pituitary-adrenal function in the rat foetus, 396

hormone production in the foetal and neonatal prostate, 447

human foetal Prl but not TSH secretion is decreased by bromocriptine, 35

ontogenetic development of pancreatic THR in human foetuses, 372

\section{FOLLICLE STIMULATING HORMONE}

human $\mathrm{FSH}$; regulation of the clearance rate in mice by variation of the molecular structure, 336 pituitary adenoma secreting FSH and LH in a young fertile woman without primary gonadal failure, 58

\section{FORSKOLIN}

effects on isolated rat corpora lutea, 571

\section{GASTRIC INHIBITORY POLYPEPTIDE}

effects of Acarbose on the relationship between changes in GIP and insulin responses to meals in normal subjects, 361

in obese hyperglycaemic (ob/ob) mice; influence of diet, 224

\section{GASTRIC SOMATOSTATIN-LIKE IMMUNOREACTIVITY sEe SOMATOSTATIN}

\section{GASTROINTESTINAL TRACT}

absorption of l-deamino-8-D-arginine vasopressin from different regions of the gastrointestinal tract in rabbits, 457

\section{GENDER REASSIGNMENT}

in male pseudohermaphroditism in early infancy, 238

\section{GESTAGENS}

norethisterone; A-ring reduction enhances its antigonadotropic potency, 278

\section{GLUCOSE}

glucose tolerance in early human pregnancy; insulin and glucagon responses, 263

serum levels in male rats; time course of the effect of streptozotocin, 300

\section{GOITRE}

assay for thyroid growth stimulating immunoglobulins in goịtrous patients, 523

goitre epidemiology; thyroid volume, iodine excretion, $\mathrm{Tg}$ and TSH in Germany and Sweden, 494

thyroid growth modulating factors in sera of patients with non-toxic goitre, 502

$\mathrm{T}$-suppressor cell defects in euthyroid non-epidemic goitre, 83

\section{GONADOTROPINS}

human $\mathrm{FSH}$; regulation of the clearance rate in mice by variation of the molecular structure, 336

\section{GRAVES' DISEASE}

development of Graves' disease during immunosuppression for haemolytic anaemia, 531

Graves' IgG; specific stimulatory effects on release of $\mathrm{T}_{3}$ from the patients' own thyroids, 204

interactions between TSH binding inhibiting - and adenylate cyclase stimulating - antibodies in Graves' disease, 517

thyroid glands in Graves' disease are sources of TSHbinding inhibitory activity, 351

\section{GROWTH}

inulin-like growth factors; effect on human foetal, adult normal and tumour pituitary function in culture, 49

\section{GROWTH HORMONE}

circulating $\mathrm{GH}$ forms in type 1 diabetic subjects, 547 GRH does not stimulate phophoinositides breakdown in cultures of rat and human pituitary cells, 345 infarction of a pituitary $\mathrm{GH}$-secreting macroadenoma during a TRH test, 172

methionyl hGH; treatment of Turner's syndrome, 130

theophylline blunts the GH-response to GRH in normal subjects, 473

\section{HEPATOMAS}

insulin binding to hepatoma cell line $\mathrm{H} \mathrm{35,559}$

\section{HUMAN CHORIONIC GONADOTROPIN SEe CHORIONIC GONADOTROPIN}

\section{HYPERCALCAEMIA}

renal tubular reabsorption of calcium in familial hypocalciuric hypercalcaemia, 541

\section{HYPERGLYCAEMIA}

gastric inhibitory polypeptide and intestinal $\mathrm{K}$ cell hyperplasia in obese hyperglycaemic (ob/ob) mice; effect of diet, 224

\section{HYPERPROLACTINAEMIA}

comparison between pituitary computed tomographic findings and tests of hypothalamopituitary function, 20

\section{HYPERTENSION}

adrenal hypertension regeneration in rats; relative importance of gluco- and mineralocorticosteroids, 389 


\section{HYPERTHYROIDISM}

intellectual impairment after hyperthyroidism, 185

neonatal hyperthyroidism causes impairment in submandibular gland-nerve growth factor ontogeny in mice, 138

\section{HYPOPHYSIS (ANTERIOR LOBE)}

caracterization of the pituitary response in the TRH test by kinetic modeling, 43

effect of insulin-like growth factors on human foetal, adult normal and tumour pituitary function in culture, 49

effects of oestrogens on the rat hypophysis; inhibition by DXM, 64

episodical secretion of TSH, 315

$\mathrm{GH}$-secreting macroadenoma; infarction during a TRH test, 172

panhypopituitarism; aldosterone; dynamic studies and effect in Sheehan's syndrome, 329

pituitary adenoma secreting FSH and $\mathrm{LH}$ in a young fertile woman without primary gonadal failure, 58

pituitary-adrenal reserve; assessment by a single-dose metyrapone test at $06.00 \mathrm{~h}, 28$

pituitary computed tomographic findings; comparison with tests of hypothalamo-pituitary function in hyperprolactinaemia, 20

pro-opiomelanocortin-related peptides; dysregulation in neurotic depression, 1

stereotactic radiosurgery to the hypophysis in Cushing's disease, 310

\section{HYPOTHALAMUS}

brain TRH; postnatal development in male and female rats, 7

effect on dysregulation of plasma pro-opiomelanocortin-related peptides in neurotic depression, 1

hypothalamic defects in patients with septo-optic dysplasia, 305

hypothalamo-pituitary function tests in hyperprolactinaemia; comparison with pituitary computed tomographic findings, 20

ovine CRF in dogs; dose-response relationships and effects of dexamethasone, 12

\section{HYPOTHYROIDISM}

subclinical hypothyroidism; responses of total and 'free' thyroid hormones and DIT to bovine TSH, 509

\section{IMMUNOGLOBULINS}

assay for thyroid growth stimulating immunoglobulins from goitrous patients, 523

\section{IMMUNOLOGY}

inhibitory effects of antithyroid compounds on oxygen radical formation in human neutrophils, 210 interference with TSH receptor antibody determination by a spuriously occurring anti-bovine TSH antibody, 197

role of glucocorticoids in a complement-activated state induced by cobra venom factor in rats, 122 specific stimulatory effects of Graves' IgG on release of $\mathrm{T}_{3}$ from the patients' own thyroids, 204

$\mathrm{T}$-suppressor cell defects in euthyroid non-epidemic goitre, 83

\section{INSULIN}

Acarbose; effects on the relationship between changes in GIP and insulin responses to meals in healthy subjects, 361

characterization of insulin binding to hepatoma cell line $\mathrm{H} 35,559$

glucose tolerance in early human pregnancy; plasma insulin and glucagon responses, 263

relationship between OGT and insulin sensitivity in type 1 diabetes and in healthy man, 355

release and pancreatic insulin; reduction in young pre-diabetic rats, 367

resistance in liver cirrhosis; no modification by portosystemic surgical shunt, 377

\section{INSULIN LIKE GROWTH FACTORS}

effects on human foetal, adult normal and tumour pituitary function in culture, 49

\section{INTELLECTUAL IMPAIRMENT}

following hyperthyroidism, 185

\section{INTESTINAL K CELLS}

hyperplasia in obese hyperglycaemic mice; effect of diet, 224

\section{KIDNEYS}

renal tubular reabsorption of calcium in familial hypocalciuric hypercalcaemia, 541

$\mathrm{T}_{4}$ monodeiodination in normal human kidney tissue in vitro, 536

\section{LACTATION}

development of ovarian follicles during lactation in rats, 247

\section{LIPIDS}

free fatty acids and pancreatic function in the duck, 100

\section{LIPOTROPIN}

abnormal $\beta$-lipotropin response to TRH and LRH in patients with affective disorder, 481

$\beta$-lipotropin dysfunction in neurotic depression. 1 
LIVER

$\mathrm{CCl}_{4}$-induced liver injury in rats; conversion of $\mathrm{T}_{4}$ to $\mathrm{T}_{3}, 89$

characterization of insulin binding to hepatoma cell line $\mathrm{H} 35,559$

chirrhosis; insulin resistance is not modified by porto-systemic surgical shunt, 377

drug metabolism in male rats; time course of the effect of streptozotocin, 300

\section{LUTEINIZING HORMONE}

effect on isolated rat corpora lutea, 571

pituitary adenoma secreting $\mathrm{LH}$ and FSH in a young woman without primary gonadal failure, 58

secretion in male rats; effect of prostaglandin $D_{2}, 180$

\section{LYMPHOCYTES}

$\mathrm{T}$-suppressor cell defects in euthyroid non-endemic goitre, 83

\section{MELANOCYTE STIMULATING HORMONE}

long-term trophic action of $\alpha$-MSH on zona glomerulosa in rat adrenals, 404

\section{MELATONIN}

effects of photoperiods on melatonin and

$\mathrm{N}$-acetylserotonin in rabbits, 145

\section{MENSTRUATION}

menstrual cycle; changes of somatomedin-C levels by sex steroids, 284

\section{METYRAPONE}

single-dose metyrapone test at $06.00 \mathrm{~h}$; an accurate method for assessment of pituitary-adrenal reserve, 28

\section{MONONUCLEAR CELLS}

presence of oestrogen receptors on human blood mononuclear cells, 409

\section{N-ACETYLSEROTONIN}

effects of photoperiods on $\mathrm{N}$-acetylserotonin in rabbits, 145

\section{NEUROTIC DEPRESSION}

dysregulation of pro-opiomelanocortin-related peptides in the patients, 1

\section{NEUTROPHILS}

inhibitory effects of antithyroid compounds on oxygen radical function in human neutrophils, 210

\section{NORETHISTERONE}

A-ring reduction enhances its antigonadotropic potency, 278

\section{OESTRADIOL}

effect on stress-induced Prl secretion in rats, 79 oestradiol-induced $\mathrm{Prl}$ secretion in rats; effects of oestriol and tamoxifen, 71

splanchnic extraction of oestradiol in human subjects, 442

\section{OESTRIOL}

effect of oestriol and tamoxifen on oestradiol-induced $\mathrm{Prl}$ secretion in rats, 71

\section{OESTROGENS}

effects on the rat hypophysis; inhibition by dexamethasone, 64

in the foetal and neonatal prostate, 447

oestrogen receptors; presence in human blood mononuclear cells and thymocytes, 409

splanchnic extraction of oestrone and oestradiol and production of oestrone sulphate in man, 442

\section{OESTRONE}

serum and urinary oestrone sulphate in pregnancy and delivery, 423

splanchnic extraction of oestrone and oestradiol and production of oestrone sulphate in man, 442

\section{OESTROUS CYCLE}

hormone concentrations and blood gas levels during the oestrous cycle in ewes, 253

\section{OVARIES}

adenylate cyclase activity in rat corpora lutea, 565 development of ovarian follicles during lactation in rats, 247

effects of forskolin, $\mathrm{LH}$ and prostaglandin $\mathrm{F}_{2} \alpha$ on rat corpora lutea, 571

\section{OXYTOCIN}

pharmacokinetics in the human of a new vasopressin and oxytocin uterine antagonist, 465

\section{PAEDIATRICS}

ontogenetic development of pancreatic TRH in human foetuses and in infants, 372

\section{PANCREAS}

free fatty acids and pancreatic function in the duck, 100

pancreatic insulin is reduced in young prediabetic BB rats, 367

pancreatic TRH; ontogenetic development in human foetuses and in infants, 372

\section{PARTURITION}

effects of progesterone-induced postmaturity on $\mathrm{CBG}$ and pituitary-adrenal function in the rat foetus, 396 
serum and urinary oestrone sulphate during delivery, 423

\section{PHORBOL ESTERS}

effects on protein phosphorylation and free $T_{3}$ release by mouse thyroids, 217

\section{PHOSPHOINOSITIDES}

GRH does not stimulate the breakdown in cultures of rat and human pituitary cells, 345

\section{PHOSPHORYLATION}

effects of phorbol esters on protein phosphorylation and free $\mathrm{T}_{3}$ release by mouse thyroids, 217

\section{PHOTOPERIODS}

effects of different photoperiods on melatonin and $\mathrm{N}$-acetylserotonin in rabbits, 145

\section{PINEAL BODY}

effects of different photoperiods on melatonin and $\mathrm{N}$-acetylserotonin in rabbits, 145

\section{PLACENTA}

placental protein 14 ; synthesis by human decidua in vitro, 271

\section{PLASMINOGEN ACTIVATORS}

in testis during postnatal development in the rat, 431

\section{PORTO-SYSTEMIC SURGICAL SHUNT}

no modification of insulin resistance in human liver cirrhosis, 377

\section{POSTMATURITY}

effects of progesterone-induced postmaturity on $\mathrm{CBG}$ and pituitary-adrenal function in the rat foetus, 396

\section{PREGNANCY}

affinity to lectin, biological and immunological characteristics of hCG, 579

amniotic fluid vasopressin is likely to be a marker for foetal stress in rhesus erythroblastosis, 267 glucose tolerance in early human pregnancy, 263 hormone concentrations and blood gas levels during pregnancy in ewes, 253

human decidua synthesizes placental protein 14 in vitro, 271

serum and urinary oestrone sulphate in pregnancy and delivery, 423

\section{PROGESTERONE}

effect on stress-induced Prl secretion in rats, 79 effects of progesterone-induced postmaturity on CBG and pituitary-adrenal function in the rat foetus, 396

\section{PROLACTIN}

bromocriptine treatment of Prl-secreting macroadenomas, 487

human foetal Prl but not TSH secretion is decreased by bromocriptine, 35

hyperprolactinaemia; comparison between pituitary computed tomographic findings and tests of hypothalamo-pituitary function, 20

release of $\mathrm{Prl}$ in rats; effect of prostaglandin $\mathrm{D}_{2}, 180$ secretion in rats; effect of oestriol and tamoxifen on the oestrogen-induced secretion, 71

stress-induced secretion in rats; effects of oestradiol and progesterone, 79

\section{PRO-OPIOMELANOCORTIN}

related peptides; dysregulation in neurotic depression, 1

\section{PROSTAGLANDINS}

effect of $\mathrm{PGD}_{2}$ on release of $\mathrm{LH}$ in rats, 180

effect of $\mathrm{PGF}_{2} \alpha$ on isolated rat corpora lutea, 571

\section{PROSTATE}

hormone levels in the foetal and neonatal prostate, 447

\section{PSEUDOHERMAPHRODITISM}

gender reassignment in early infancy, 238

\section{PSYCHIATRY}

abnormal $\beta$-endorphin and $\beta$-lipotropin responses to LRH and TRH in affective disorders, 481

$\beta$-lipotropin dysregulation in neurotic depression, 1

\section{RADIOIMMUNOASSAYS}

direct RIA of serum and urinary oestrone sulphate in pregnancy and delivery, 423

\section{RELEASING HORMONES}

CRF ; effect of angiotensin II on o-CRF-provoked ACTH secretion in man, 150

CRF; o-CRF in dogs; dose-response relationships and effects of dexamethasone, 12

$\mathrm{CRF}$; repetitive and continuous administration of $h$ CRF to human subjects, 157

GRH; no stimulation of phosphoinositides breakdown in cultures of rat and human pituitary cells, 345

GRH; theophylline blunts the GH-response to GRH in normal subjects, 473

LRH; abnormal $\beta$-endorphin and $\beta$-lipotropin responses to LRH and TRH in patients with affective disorders, 481

LRH; dose and time effects of treatment with an LRH agonist on testicular axis and accessory sex organs in rats, 595 
TRH; abnormal $\beta$-endorphin and $\beta$-lipotropin responses to TRH and $\mathrm{LRH}$ in patients with affective disorders, 481

TRH; brain TRH; postnatal development in male and female rats, 7

TRH; characteristics of the pituitary response in the TRH test by kinetic modeling, 43

TRH ; infarction of a $\mathrm{GH}$-secreting pituitary macroadenoma during a TRH test, 172

TRH; ontogenetic development of pancreatic TRH in human foetuses and in infants, 372

\section{RELAXIN}

local administration induces changes in the microcirculation of the rat mesocaecum, 296

\section{RENIN}

divergent effects of chloride restriction on aldosterone biosynthesis and the renin-angiotensin system in rats, 105

\section{RIBONUCLEIC ACID}

effect of ACTH on RNA synthesis and migration in adrenocortical cells of rats, 114

\section{SALIVA}

identification and measurement of sex hormone binding globulin and corticosteroid binding globulin in human saliva, 603

\section{SALIVARY GLANDS}

submandibular gland-nerve growth factor ontogeny in mice; impairment by neonatal hyperthyroidism, 138

\section{SEPTO-OPTIC DYSPLASIA}

hypothalamic defects in two patients, 305

\section{SEROTONIN}

effects of photoperiods on melatonin and

$\mathrm{N}$-acetylserotonin in rabbits, 145

\section{SEX HORMONE BINDING GLOBULIN}

in human saliva, 603

\section{SHEEHAN'S SYNDROME}

dynamic studies and therapeutic effects of aldosterone, 329

\section{SOMATOMEDIN}

changes of somatomedin-C levels by sex steroids during the menstrual cycle, 284

\section{SOMATOSTATIN}

gastric somatostatin-like immunoreactivity; development in young rats in response to corticosterone and dietary changes, 383
SOMATOTROPIN see GROWTH HORMONE

\section{STREPTOZOTOCIN}

time course of the effect on serum glucose and triglycerides and on the hepatic drug metabolism in rats, 300

\section{STRESS see ADAPTATION SYNDROME}

\section{SUBMANDIBULAR GLANDS}

neonatal hyperthyroidism causes impairment in the submandibular gland-nerve factor ontogeny in mice, 138

of the mouse; ontogenesis of androgen receptors and correlation with thyroid and testicular hormones, 290

\section{TAMOXIFEN}

effect on oestradiol-induced prolactin secretion in rats, 71

\section{TESTES}

cisplatin; effects on the mouse testis, 436

dose and time effects of an LRH agonist on testicular axis and accessory sex organs in rats, 595

testicular plasminogen activators during postnatal development in the rat, 431

\section{TESTOSTERONE}

developmental profiles of circulating testicular hormones in the mouse submandibular gland, 290 testosterone and DHT in the foetal and neonatal prostate, 447

\section{3, 5, 3', 5'-TETRAIODOTHYROACETIC ACID} serum levels in hypo-, hyper- and euthyroidism, 192

\section{THEOPHYLLINE}

blunts the GH-response to GRH in normal subjects, 473

\section{THYMUS}

presence of oestrogen receptors in human thymocytes, 409

\section{THYROGLOBULIN}

goitre epidemiology; thyroid volume, iodine excretion, Tg and TSH in Germany and Sweden, 494

intrathyroidal Tg in streptozotocin-diabetic rats, 552

\section{THYROID}

assay of thyroid growth stimulating immunoglobulins, 523

development of Graves' disease during immunosuppression for haemolytic anaemia, 531 
diseases; serum levels of $3,5,3$ ', 5'tetraiodothyroacetic acid in hypo-, hyper-and euthyroidism, 192

goitre epidemiology; thyroid volume, iodine excretion, Tg and TSH in Germany and Sweden, 494

hormones; developmental profiles of circulating thyroid hormones in the mouse submandibular gland, 290

hormones; postnatal development in male and female rats, 7

hyperthyroidism; intellectual impairment in the patients, 185

hyperthyroidism (neonatal) causes impairment in submandibular gland-nerve growth factor ontogeny in mice, 138

subclinical hypothyroidism; responses of total and 'free' thyroid hormones and DIT to bovine TSH, 509

thyroid glands of Graves' disease are sources of

TSH-binding inhibitory activity, 351

thyroid growth modulating factors in sera of patients with non-toxic goitre, 502

$\mathrm{T}$-suppressor cell defects in euthyroid non-endemic goitre, 83

\section{THYROIDECTOMY}

effect of maternal thyroidectomy on foetal brain development in sheep, 93

\section{THYROTROPIN}

characterization of the pituitary response in the TRH test by kinetic modeling, 43

episodical secretion of TSH, 315

goitre epidemiology; thyroid volume, iodine excretion, Tg and TSH in Germany and Sweden, 494

human foetal Prl but not TSH is decreased by bromocriptine, 35

interactions between TSH binding inhibiting - and adenylate cyclase stimulating - antibodies in Graves' disease, 517

interference with TSH receptor antibody determination by a spuriously occurring anti-bovine TSH antibody, 197

postnatal development of TSH in male and female rats, 7

responses of total and 'free' thyroid hormones and DIT to bovine TSH in subclinical hypothyroidism, 509

TSH-binding inhibitory activity; thyroid glands in patients with Graves' disease are sources, 351

\section{THYROXINE}

conversion of $T_{4}$ to $T_{3}$ in perfused liver of rats with $\mathrm{CCl}_{4}$-induced liver injury, 89

$\mathrm{T}_{4}$ monodeiodination in normal kidney tissue in vitro, 536

\section{TRIGLYCERIDES}

serum levels in male rats; time course of the effect of streptozotocin, 300

\section{TRIIODOTHYRONINE}

conversion of $T_{4}$ to $T_{3}$ in perfused liver of rats with $\mathrm{CCl}_{4}$-induced liver injury, 89

effects of phorbol esters on free $T_{3}$ release by mouse thyroids, 217

release of $T_{3}$ from the patients' own thyroids; specific stimulatory effects of Graves' IgG, 204

\section{TUMOURS}

hepatomas; characterization of insulin binding to hepatoma cell line $\mathrm{H} 35,559$

pituitary adenoma secreting $\mathrm{FSH}+\mathrm{LH}$ in a young fertile woman, 58

pituitary $\mathrm{GH}$-secreting macroadenoma; infarction during a TRH test, 172

pituitary Prl-secreting macroadenomas; bromocriptine treatment, 487

trophoblastic tumours; affinity to lectin, biological and immunological characteristics of hCG, 579

\section{TURNER'S SYNDROME}

treatment with methionyl human growth hormone, 130

\section{UTERUS}

cannulation of the utero-ovarian vein in intact ewes, 253

pharmacokinetics in the human of a new vasopressin and oxytocin uterine antagonist, 465

\section{VASOPRESSIN}

amniotic fluid arginine vasopressin is likely to be a marker for foetal stress in rhesus erythroblastosis, 267

I-deamino-8-D-arginine vasopressin; absorption from different regions of the gastrointestinal tract in rabbits, 457

haemodynamic role of vasopressin released during Finnish sauna, 166

pharmacokinetics in the human of a new vasopressin and oxytocin uterine antagonist, 465 


\title{
Goitre epidemiology: thyroid volume, iodine excretion, thyroglobulin and thyrotropin in Germany and Sweden
}

\author{
R. Gutekunst, H. Smolarek, \\ U. Hasenpusch ${ }^{2}$, P. Stubbe ${ }^{2}$, H.-J. Friedrich', \\ W. G. Wood and P. C. Scriba \\ Klinik für Innere Medizin, Institut für Medizinische Statistik und Dokumentation, \\ Medical University of Lübeck \\ Zentrum für Kinderheilkunde ${ }^{2}$, University Göttingen, FRG
}

\begin{abstract}
Thyroid volume of 1397 German and 303 Swedish adults were estimated by sonography. Thyroid size of $6-16$ year old Germans $(n=619)$ was determined and compared with findings on palpation. Thyroid volume was more than twice as great in German $(21.4 \pm 15.6 \mathrm{ml}$, mean $\pm \mathrm{SD})$ than in Swedish adults $(10.1 \pm 4.9 \mathrm{ml})$. The echopattern was abnormal in $16 \%$ of the Germans and in $3.6 \%$ of the Swedes. German children have a thyroid volume ranging from $1.8 \pm 0.4$ $\mathrm{ml}$ at 6 years to $10.8 \pm 6.0 \mathrm{ml}$ at 16 years of age. Palpation is by comparison an unreliable method for determining thyroid size. In Germany, the iodine excretion was less in children $(n=619,39.5 \pm 30.5,34.1$ $\mu \mathrm{g} \mathrm{I} / \mathrm{g}$ creatinine, mean $\pm \mathrm{SD}$, median) than in adults (n $=1193,83.7 \pm 94.4,62.6),(P<0.001)$ and much lower than that observed in Sweden (adults $\mathrm{n}=98,170.2 \pm$ $93.3,141.4 ; 13$ year olds $n=113,172.9 \pm 224.1,124)$, $(P<0.0001)$. Serum thyrotropin concentration was significantly higher $(P<0.001)$ in Sweden $(\mathrm{n}=62,1.49 \pm$ $0.82 \mathrm{mU} / \mathrm{ml})$, than in Germany $(\mathrm{n}=91,0.97 \pm 0.52$ $\mathrm{mU} / \mathrm{ml}$ ), while serum thyroglobulin was increased in Germany $(\mathrm{n}=91,72.6 \pm 50.6 \mu \mathrm{g} / \mathrm{l})$ as compared to Sweden $(\mathrm{n}=62,23.5 \pm 17.4),(P<0.0001)$. These results indicate the goitrogenic effect of iodine deficiency and the continuing need for an effective iodine prophylaxis in the FRG.
\end{abstract}

Alimentary iodine supply in Germany is insufficient and goitre is endemic (Horster et al. 1975). There are, however, no iodine excretion measure-

Dedicated to Prof. Dr. med. E. Buchborn, Munich, at the occasion of his 65 th birthday. ments for adults available. Urinary iodine excretion is generally considered to be equivalent to alimentary iodine intake. Habermann et al. (1975) found an iodine excretion of $25-35 \mu \mathrm{g} \mathrm{I} / \mathrm{g}$ creatinine in 13-15 year olds. This was far below the iodine intake recommended by WHO with an optimum of $150-300 \mu$ g iodine daily (Dunn et al. 1974).

Previous epidemiological studies on goitre in adults were obtained by evaluating chest-X-rays from public health service screening programmes, (Finger et al. 1982; Schoknecht \& Barich 1975), as well as by palpation of military recruits' necks (Horster et al. 1975). Goitre prevalence studies for children were solely based on palpation (Habermann et al. 1975; Stubbe \& Heidemann 1983). A representative study of the general population has not yet been undertaken.

Sonographic volumetry is now considered the most reliable method to determine thyroid volume (Brunn et al. 1981; Gutekunst et al. 1985; Hedegüs et al. 1983). Since iodine supply in Sweden is sufficient (Gutekunst et al. 1985) a comparison of iodine excretion, thyroid size and thyroid function in Germany and Sweden was carried out. In this study we examined the reliability of palpation for goitre epidemiological studies in children. Furthermore, we attempted to gain new data about alimentary iodine supply and goitre prevalence. 


\section{Subjects and Methods}

Thyroid volume from 1397 German adults in 7 towns (from north to south, Kiel $n=46$, Lübeck $n=70$, Berlin $n=111$, Wolfsburg $n=313$, Frankfurt $n=226$, Tutzing $n=339$, Penzberg $n=293$ ), from 619 children, 6-16 year old from two schools near Göttingen and from 303 adults from Stockholm, Sweden, were determined by ultrasound. Length, width, and thickness of both thyroid lobes were measured with portable ultrasound equipment (Sonoline 1300, Siemens, Erlangen, FRG; transducer $4 \mathrm{MHz}$ ). Echo structure deviations were recorded and reported to the subjects' physicans. The volume was estimated by multiplication of thickness, width, length and a corrective factor $(0.479)$ (Brunn et al. 1981). There was no selection process for the adult volunteers who were employees of large companies.

Children's necks were palpated for estimation of thyroid size according to WHO staging (Dunn et al. 1974), by an independent experienced paediatrician.

Spot urine samples were collected from 1812 Germans (adults, $n=1193$, children, $n=619$ ) and 211 Swedes (adults $n=98,13$ year old children $n=113$ ). The determination of urinary iodine excretion was performed by a modified ceric arsenious acid wet ash method according to Wawschinek, (1985). The kinetic determination of creatinine followed Jaffe's method (Beckman creatinine analyser, ASTRA-IV).
Serum thyrotropin (TSH) from a random selection of 91 German adults and 62 Swedes was measured by a hypersensitive immunoradiometric assay (IRMA) from Behring company (Wood et al. 1985), and serum thyroglobulin by an immunoluminometric assay (ILMA) (Gadow et al. 1984).

Finally, the use of iodized salt $(20 \mathrm{mg}$ iodine as potassium iodate per $\mathrm{kg}$ ), which is available only on a voluntary basis in the FRG, was investigated by interrogation.

\section{Thyroid volume}

Among Swedish adults, women have a thyroid volume of $7.7 \pm 4.3 \mathrm{ml}$ (mean $\pm \mathrm{SD}$ ) with a range of $2.5-34.0 \mathrm{ml}$ and a median of $6.9 \mathrm{ml}$; and men $11.1 \pm 4.7 \mathrm{ml}$ (range $3.3-27.4 \mathrm{ml}$ ) and median $9.1 \mathrm{ml}$. German adults had much larger volume: women, $16.5 \pm 12.2 \mathrm{ml}$, median $13.3 \mathrm{ml}$, range 2.6-124.1 ml; men $26.9 \pm 17.0 \mathrm{ml}$, median 23.1 $\mathrm{ml}$, range $3.8-105.0 \mathrm{ml}$. The difference between the thyroid volume in Swedes and Germans is highly significant $(P<0.0001)$. Fig.1 shows the distribution of volume in both countries. The frequency distribution in Germany as compared

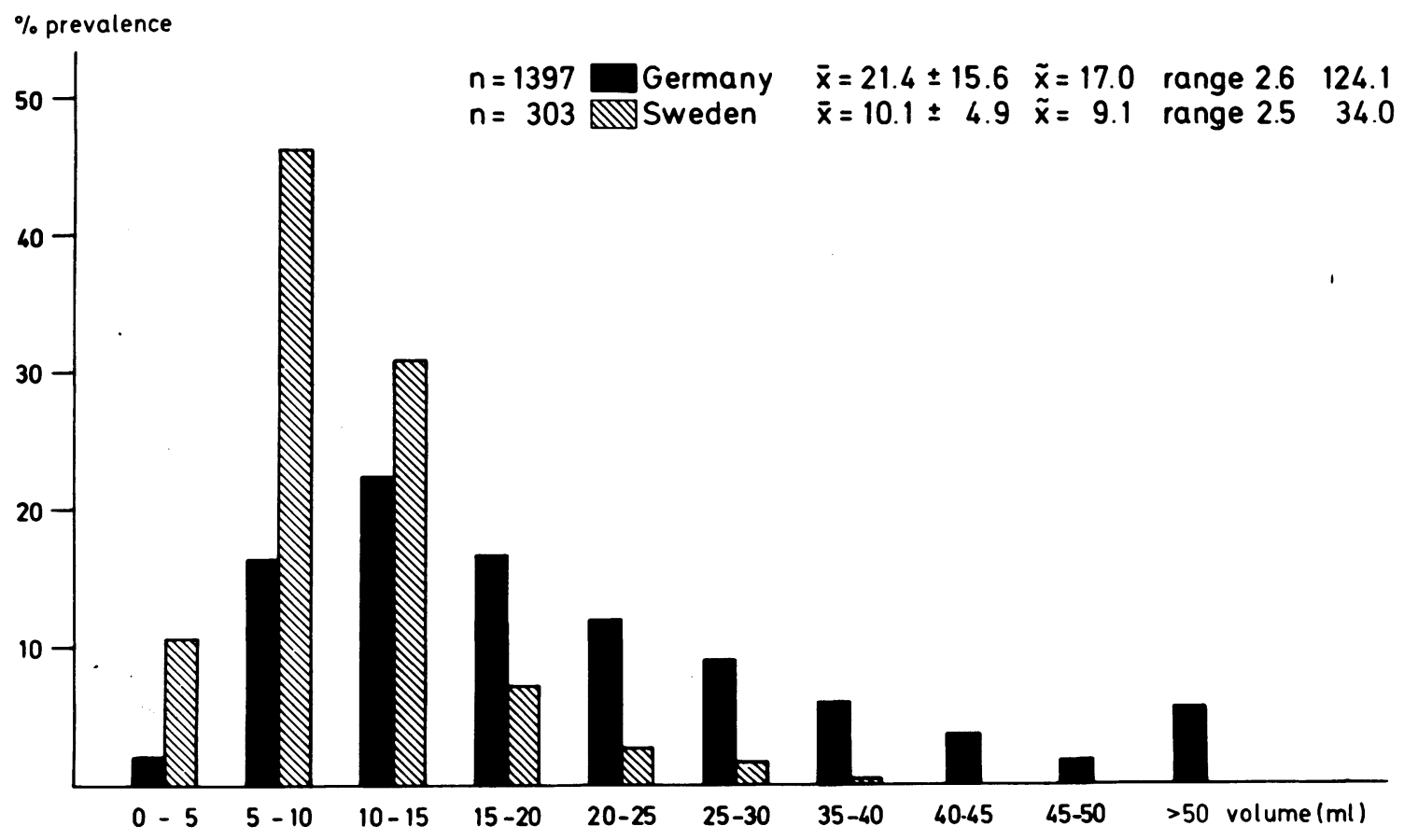

Fig. 1.

Frequency distribution of thyroid volume $(\mathrm{ml})$ in Germany and Sweden. 


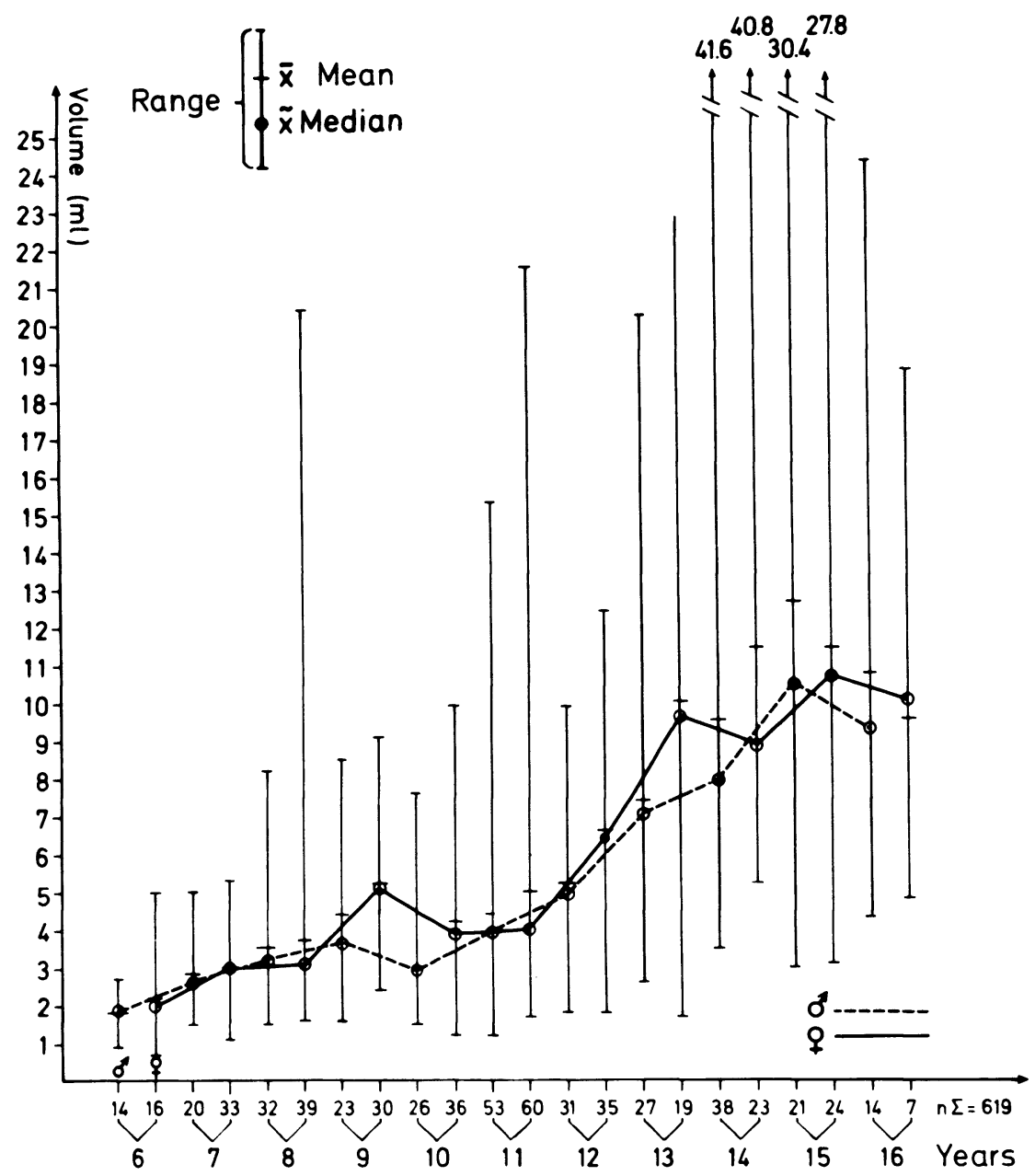

Fig. 2.

Thyroid volume ( $\mathrm{ml}$ ) in 6-16 years old from Göttingen, FRG.

to Sweden is shifted toward larger volume $(P<0.0001)$.

Six year old German children had volume of 1.8 $\pm 0.4 \mathrm{ml}$ which progressively increased to 10.8 $\pm 6.0 \mathrm{ml}$ at age 16 years $(P<0.001)$ (Fig. 2). Palpation in children for thyroid size is rather unreliable. As seen in Figs. 3 and 4, ranges of thyroid volume determined sonographically overlap widely in the respective age groups with volume estimated by palpation (goitre 0, I, II).

\section{Echopatterns (Table 1)}

Eighty-four per cent of the German adults had a normal echopattern; $2.5 \%$ had a scattered sonolucent pattern and $0.1 \%$ a scattered echocomplex pattern; $13.4 \%$ had unifocal and/or multifocal echo alterations; $5.9 \%$ had cysts; $2.1 \%$ had calcifi- cations; $3.2 \%$ had sonolucent nodules; $2.1 \%$ had echosolid nodules; and $0.1 \%$ had echocomplex nodules.

Ninety-six per cent of the Swedes had a normal echopattern; $1 \%$ had scattered sonolucent thyroids; $0.3 \%$ had calcifications; $1.3 \%$ had cysts; $0.3 \%$ had sonolucent nodules; and $0.7 \%$ had echosolid nodules.

\section{Iodine excretion}

Adults. Urinary iodine excretion was significantly lower in Germany as compared to Sweden (83.7 \pm 94.4, 62.6 $\mu \mathrm{g} \mathrm{I} / \mathrm{g}$ creatinine, vs $170.2 \pm 93.3$, 14 1.4, mean \pm sD, median $),(P<0.0001)$. Thirtyone urine samples from German subjects were contaminated with iodine $(>1063.5 \mu \mathrm{g} \mathrm{I} / \mathrm{g}$ creatinine). Fig. 5 illustrates the frequency distribution 


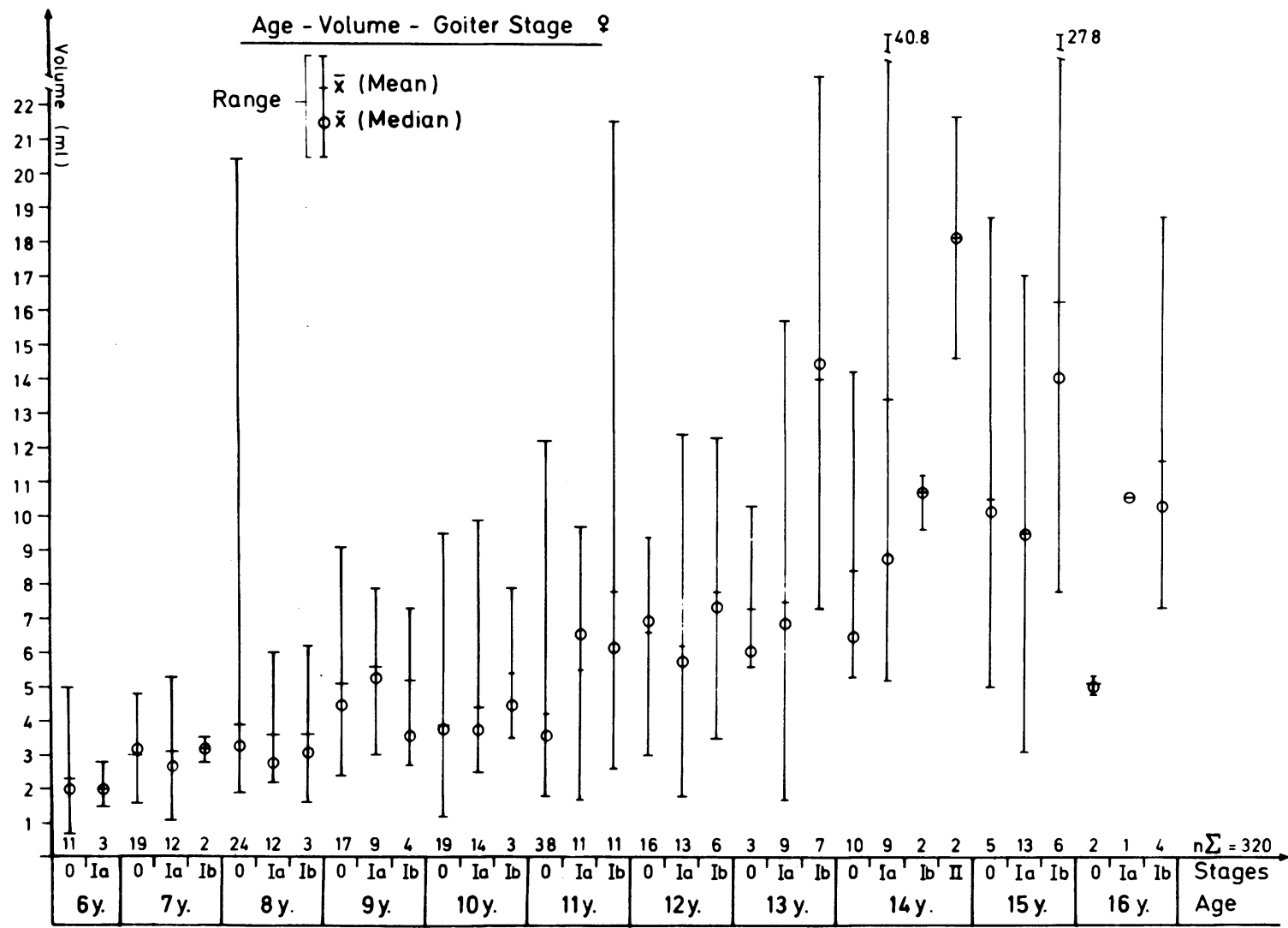

Fig. 3.

Sonographically determined thyroid volume as compared with respective palpatory goitre stages for girls 6-16 years old.

for iodine excretion in both countries. The Swedish distribution shows clearly higher values.

Children. Urinary iodine excretion was low in all age groups in Germany $(39.6 \pm 30.5,34.1 \mu \mathrm{g} \mathrm{I} / \mathrm{g}$ creatinine, mean $\pm \mathrm{SD}$, median) and more than twice as high in Sweden (172.9 $\pm 224.1,124)$, $(P<0.0001)$.

\section{Comparison of iodine excretion to thyroid volume in German adults}

Table 2 shows the median iodine excretion and thyroid volume from cities extending from north to south. The variation from north to south is hardly noticeable, although iodine excretion is higher and thyroid volume is smaller in coastal towns compared to the rest of Germany.

\section{Iodized salt}

There is little difference between iodine excretion of subjects (children and/or adults) using iodized salt and those not ingesting iodine salt $(P>0.05)$. Thyroid volume also did not differ.

\section{TSH and TG levels (Table 3)}

Surprisingly, basal serum TSH levels were lower in German adults $(0.97 \pm 0.52 \mathrm{mU} / \mathrm{ml})$ than in Swedes $(1.49 \pm 0.82 ; P<0.001)$, whereas the mean serum thyroglobulin concentrations in German adults $(72.6 \pm 50.6 \mu \mathrm{g} / \mathrm{l})$ was more than twice as high as in the Swedes $(23.5 \pm 17.4 ; P<0.0001)$.

\section{Discussion}

The observation that iodine deficiency has a goitrogenic effect was again supported by the comparison of thyroid volume and iodine excretion between Germans and Swedes. The German adults' thyroids are more than twice as large as those observed in Swedish adults. These findings 


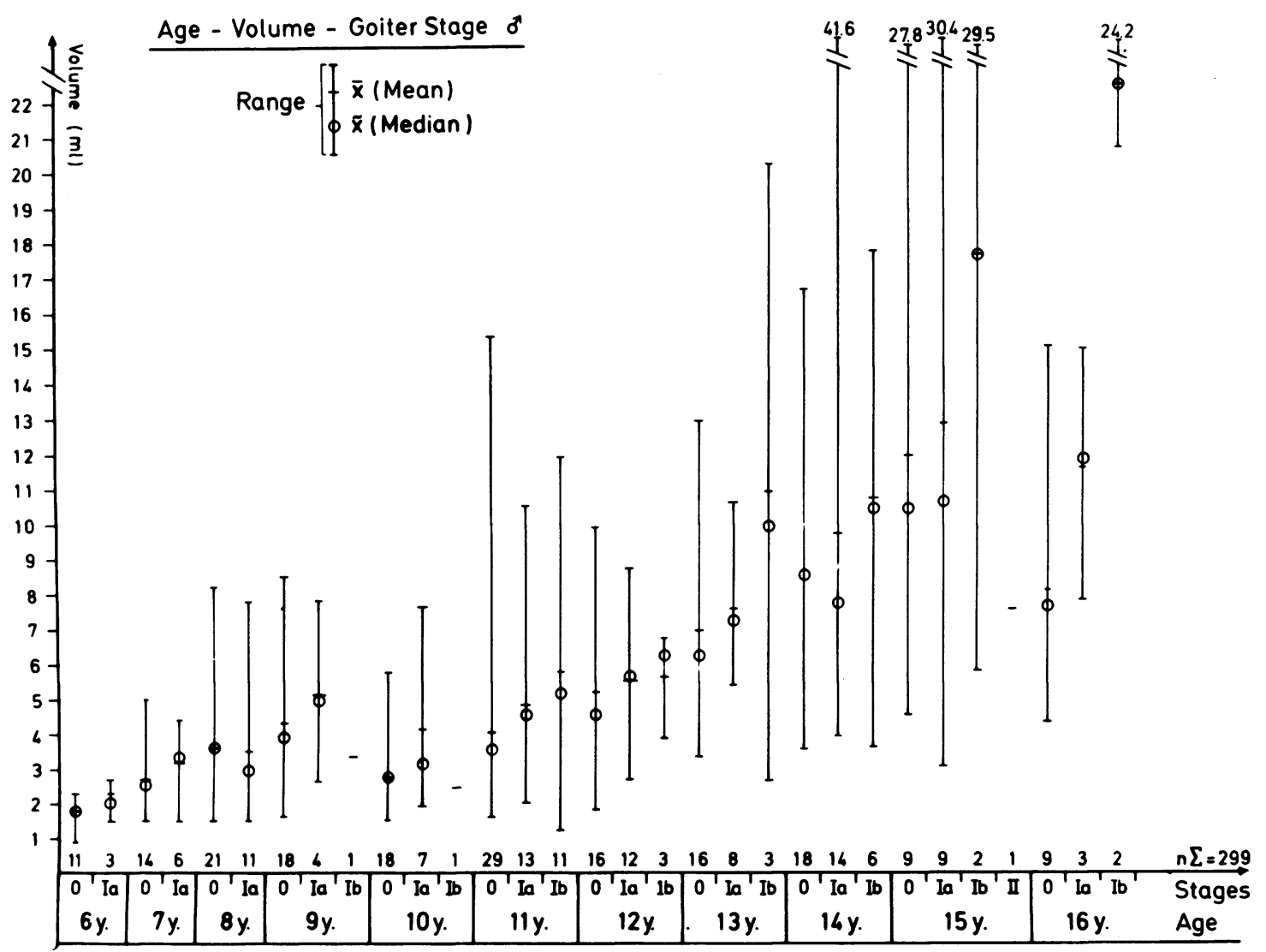

Fig. 4.

Sonographically determined thyroid volume as compared with respective palpatory goitre stages for boys 6-16 years old.

confirm the results of our previous study of 2468 13 year old children in Germany and Sweden, (Gutekunst et al. 1985). In this study, 9 year old German children already exhibited larger thyroid volume compared to those in 13 year old Swedish children. Since it is impossible to define normal thyroid volume in Germany, goitre prevalence cannot be determined on the basis of thyroid volumetry. However, almost one third of the German thyroids are larger than those observed in Sweden (99\% range, mean $+3 \mathrm{SD}$ ). Thirteen per cent of the German thyroids are above the largest measured Swedish volume. Accordingly, a thyroid volume larger than $20 \mathrm{ml}$ for women and $25 \mathrm{ml}$ for men should be treated or at least controlled. Forty-two per cent of the German men and $25 \%$ of the women studied belong in this category. Similarily, 'normal ranges' were defined by Olbricht et al. (1982) and Hegedüs et al. (1983).

The traditional view that goitre is predominantly a problem in Southern Germany can no longer
Table 1.

Echopatterns in Swedish and German adults.

\begin{tabular}{lccc}
\hline \multicolumn{1}{c|}{ Echopattern } & Sweden & Germany \\
\hline Normal & $96.4 \%$ & $84.0 \%$ \\
& $(\mathrm{n}=292)$ & $(\mathrm{n}=1174)$ \\
Scattered sonolucent & $1.0 \%$ & $2.5 \%$ \\
& $(\mathrm{n}=3)$ & $(\mathrm{n}=35)$ \\
Scattered echocomplex & - & $0.1 \%$ \\
& & $(\mathrm{n}=1)$ \\
Uni- and/or & $2.6 \%$ & $13.4 \%$ \\
multifocal alterations & $(\mathrm{n}=8)$ & $(\mathrm{n}=187)$ \\
Cyst(s) & $1.3 \%$ & $5.9 \%$ \\
& $(\mathrm{n}=4)$ & $(\mathrm{n}=82)$ \\
Calcification(s) & $0.3 \%$ & $2.1 \%$ \\
& $(\mathrm{n}=1)$ & $(\mathrm{n}=29)$ \\
Sonolucent nodule(s) & $0.3 \%$ & $3.2 \%$ \\
& $(\mathrm{n}=1)$ & $(\mathrm{n}=46)$ \\
Echosolid nodule(s) & $0.7 \%$ & $2.1 \%$ \\
& $(\mathrm{n}=2)$ & $(\mathrm{n}=29)$ \\
Echocomplex nodule(s) & - & $0.1 \%$ \\
& & $(\mathrm{n}=1)$ \\
\hline
\end{tabular}




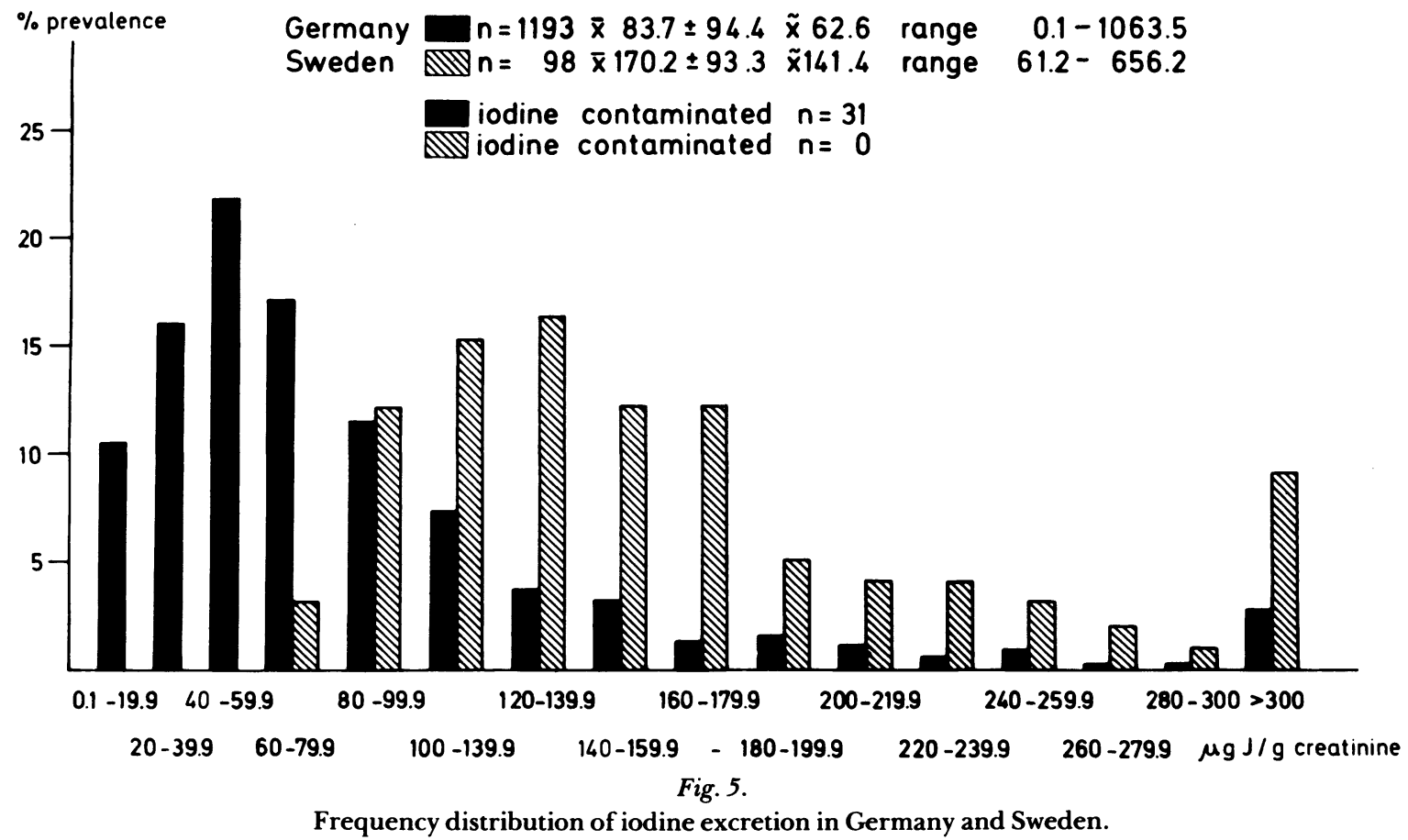

be maintained. As previously found with children in 23 German towns, (Gutekunst et al. 1985), there is likewise no clear-cut increase of thyroid

Table 2.

Comparison of medians of iodine excretion $(\mu \mathrm{g} \mathrm{I} / \mathrm{g}$ creatinine) and thyroid volume $(\mathrm{ml})$ from Northern to Southern Germany.

\begin{tabular}{lccc}
\hline & $\begin{array}{c}\text { Iodine } \\
(\mu \mathrm{g} \mathrm{I} / \mathrm{g} \text { creatinine })\end{array}$ & $\begin{array}{c}\text { Thyroid volume } \\
(\mathrm{ml})\end{array}$ \\
\hline Kiel & 67.3 & 14.3 \\
Lübeck & $(\mathrm{n}=46)$ & $(\mathrm{n}=46)$ \\
Berlin & 104.7 & 12.5 \\
$(\mathrm{n}=63)$ & $(\mathrm{n}=70)$ \\
Wolfsburg & 61.9 & 15.2 \\
Frankfurt & $(\mathrm{n}=98)$ & $(\mathrm{n}=111)$ \\
Tutzing & 48.2 & 18.7 \\
& $(\mathrm{n}=230)$ & $(\mathrm{n}=313)$ \\
Penzberg & 64.2 & 18.8 \\
& $(\mathrm{n}=201)$ & $(\mathrm{n}=224)$ \\
& 64.8 & 18.5 \\
Total & $(\mathrm{n}=291)$ & $(\mathrm{n}=339)$ \\
& 66.0 & 14.5 \\
& $(\mathrm{n}=264)$ & $(\mathrm{n}=293)$ \\
\hline
\end{tabular}

size in adults from north to south. Similarily, endemic nests have to be expected especially in the central region of the FRG. However, in order to obtain a satisfactory mapping of goitre prevalence and iodine deficiency in the FRG, and extensive investigation at further locations would be necessary.

In the German population, $12.4 \%$ more abnormal sonographic echopatterns - a sign of diffuse or focal alteration of the gland - were observed than in the Swedish population. These findings are in accordance with the well-known fact that nodular goitre is mainly the consequence of thy-

Table 3.

Comparison of TSH and TG serum levels in Germany and Sweden.

\begin{tabular}{l|ccc}
\hline & $\begin{array}{c}\text { Germany } \\
(\mathrm{n}=91)\end{array}$ & $\begin{array}{c}\text { Sweden } \\
(\mathrm{n}=62)\end{array}$ \\
\hline & $\overline{\mathbf{x}}=72.6 \pm 50.6$ & $\overline{\mathbf{x}}=23.5 \pm 17.4$ \\
$\mathrm{TG}(\mu \mathrm{g} / \mathrm{l})$ & $\widetilde{\mathbf{x}}=43$ & $\widetilde{\mathbf{x}}=21.2$ \\
& range $1.6-234.7$ & range $15.0-86.0$ \\
& $\overline{\mathbf{x}}=0.97 \pm 0.52$ & $\overline{\mathbf{x}}=1.49 \pm 0.82$ \\
TSH $(\mathrm{mU} / \mathrm{l})$ & $\widetilde{\mathbf{x}}=0.9$ & $\widetilde{\mathbf{x}}=1.55$ \\
& range $0.02-2.82$ & range $0.08-3.98$ \\
& &
\end{tabular}


roid enlargement following iodine deficiency, (Hedinger 1980).

From our present observations and those in an earlier study (Gutekunst et al. 1985) it is apparent that thyroid palpation is of limited value for epidemiological goitre studies. Palpation is even less reliable in younger subjects. It is almost useless in children below 10 years of age. Although the sensitivity of palpation in adults was acceptable $(91 \%)$, the specificity decreased dramatically to $63.5 \%$.

There is no statistical relation between thyroid volume and iodine excretion in Germany, since all Germans are similarily iodine deficient. Furthermore, iodine excretion is very close to the minimum daily iodine excretion, i.e. individuals with increased tendency to develop goitre cannot be distinguished from the normal population.

This is also true for children and adults who use iodized table salt. The iodized salt in Germany contains $20 \mathrm{mg}$ iodine per $\mathrm{kg}$. To counteract this iodine deficiency, a salt intake of $5 \mathrm{~g}$ per person per day is necessary. Since iodized table salt can only be added by the individual to his own food, 5 $\mathrm{g}$ daily is obviously unrealistic. Hintze et al. (1985) reported in a 4 year follow-up that there is no significant difference in iodine excretion and goitre stages in children who use iodized salt compared to those who do not. The study of Kersting et al. (1985) suggests that a daily additional intake of more than $1-3 \mathrm{~g}$ salt is impractical.

As expected, serum thyroglobulin concentration was higher in German subjects than in those living in Sweden. This is probably due to abnormal thyroid metabolism of thyroglobulin during iodine deficiency, (Pezzino et al. 1978) as well as a greater thyroglobulin leak in degenerative goitre (Gebel et al. 1983).

The surprisingly lower TSH levels in Germany could partially be explained by a higher prevalence of 'preclinical autonomy'. This is a wellknown consequence of iodine deficiency (Fenzi et al. 1985; Pickardt et al. 1972). Our results concur with those of Delange et al. (1971) who observed no relationship between serum TSH and thyroid volume. Pickardt et al. (1972) also found no difference in serum TSH in an endemic goitre area in Bavaria. A rise in serum TSH is only observed when iodine deficiency leads to inadaequate production of $T_{4}$ and $T_{3}$ as has been reported in severe endemic goitre areas (Chopra et al. 1975).
Studies in the rat have shown that iodine depleted thyroids are much more sensitive to TSH than those with normal iodine content (Bray 1968). Possibly, the reduced TSH level is a physiological response to protect the thyroid from additional growth. It is currently disputed whether TSH is indeed a growth factor for the thyroid cell (9th Int. Thyroid Congr. 1985).

However, these explanations do not conclusively explain the significantly lower levels of serum TSH in the German population. Further investigation with supersensitive TSH-immunoassays will be necessary.

\section{Conclusions}

It is evident from the present study and those reported earlier that the iodine supply in Germany is insufficient. Goitre prevalence can be substantially decreased by an effective program of iodine prophylaxis. Since compulsory iodination of salt is at this time not possible there must be a gradual increase to $50 \mathrm{mg}$ iodine per $\mathrm{kg}$ table salt. Further ways to supply people with appropriate iodine should be considered. Increased public awareness of this problem is essential.

\section{Acknowledgments}

We thank the following companies for giving the employees time to participate in this study: Boehringer Mannheim, Brunnengräber Lübeck, Ferring Kiel, Henning Berlin, Hoechst Frankfurt, LKB Stockholm and Volkswagenwerk, Wolfsburg.

We are grateful for the support of the Freunde und Förderer of the Medical University of Lübeck.

We thank Prof. Dr. Kl. Lorentz and Dr. E. Kraas for the technical advice to measure creatinine.

The authors gratefully acknowledge the critical reading and help with the manuscript by Prof. L. Braverman, Worcester, MA, USA.

\section{References}

Bray G A (1968): Increased sensitivity of thyroid in iodine-depleted rats to the goitrogenic effects of thyrotropin. J Clin Invest 47: 1640-1644.

Brunn J, Block U, Ruf G, Bos I, Kunze W P \& Scriba P C (1981): Volumetrie der Schilddrüsenlappen mittels Real-time-Sonographie. Dtsch Med Wochenschr 106: 1338- 1340. 
Chopra I J, Hershman J M \& Hornabrook R W (1975): Serum thyroid hormone and thyrotropin levels in subjects from endemic goiter regions of New Guinea. J Clin Endocrinol Metab 40: 326-333.

Delange F, Hershman J M, Ermans M (1971): Relationship between the serum thyrotropin level, the prevalence of goiter and the pattern of iodine metabolism in Idjwi Island. J Clin Endocrinol Metab 33: 261268.

Dunn J T \& Medeiros-Neto G A (1974): Endemic goiter and cretinism: Continuing threats to world health, Pan American Health Organization, World Health Organization, Washington DC, Scientific Publication 292: 1- 195.

Fenzi G F, Ceccarelli C, Macchia E, Monzani F, Bartalena L, Giani C, Ceccarelli P, Lippi F, Baschieri L \&c Pinchera A (1985): Reciprocal changes of serum thyroglobulin and TSH in residents of a moderate endemic goitre area. Clin Endocrinol (Oxf) 23: 115122.

Finger E, Dabels J, Schünemann G \& Krüger M (1982): Strumareihenuntersuchung durch Volksröntgenaktion. Z Erkrank Atem-Org 158: 309-313.

Gadow A, Wood W G \& Scriba P C (1984): Lumineszenz-Immunoassay für die Bestimmung von Schilddrüsenparametern - Eine Alternative zum Radioimmunoassay. Akt Endokr Stoffw 5: 13-21.

Gebel F, Ramelli F, Bürgi U, Ingold U, Studer H \& Winand $R$ (1983): The site of leakage of intrafollicular thyroglobulin into the blood stream in simple human goiter. J Clin Endocrinol Metab 57: 915-919.

Gutekunst R, Smolarek H, Wächter W \& Scriba P C (1985): Strumaepidemiologie. IV. Schilddrüsenvolumina bei deutschen und schwedischen Schulkindern. Dtsch Med Wochenschr 2: 50-54.

Gutekunst R, Smolarek H, Wächter W, Scriba P C (1985): Kritik der Strumaepidemiologie. III. Vergleich von Röntgen-Thoraxaufnahmen, Palpation und sonographische Volumetrie. In: Schleusener $\mathrm{H}$ et al. (eds). Schilddrüse 1983, pp 110: 50-54. Thieme, Stuttgart.

Habermann J, Heinze H G, Horn H, Kantlehner R, Marschner I, Neumann J \& Scriba P C (1975): Alimentärer Jodmangel in der Bundesrepublik Deutschland. Dtsch Med Wochenschr 100: 1937- 1945.

Hedinger C \& Egloff B (1980): Normale und pathologische Anatomie der Schilddrüse. In: Oberdisse K, Klein E, Reinwein D (eds). Die Krankheiten der Schilddrüse, pp 6-47. Thieme Verlag Stuttgart New York.

Hegedüs L, Perrild H, Poulsen L R, Andersen J R, Holm B, Schnohr P, Jensen G \& Hansen J M (1983): The determination of thyroid volume by ultrasound and its relationship to body weight, age and sex in normal subjects. J Clin Endocrinol Metab 56: 260263.
Hintze J, Köbberling J, Emrich D, Wasielewski Th \& Thal $H$ (1985): Influence of iodinated salt on goiter frequency in 10-year old school children - preliminary result after two years. Acta Endocrinol (Copenh) 108. Suppl 267: 80-81.

Horster F A, Klusmann G \& Wildmeister W (1975): Der Kropf: eine endemische Krankheit in der Bundesrepublik? Dtsch Med Wochenschr 100: 8-9.

Kersting M, Gottge M, Wember Th, Weber P, Manz F \& Schöch G (1985): Welche Chancen bietet die Verwendung von jodiertem Speisesalz für die Bekämpfung des endemischen Jodmangels? Ernährungs-Umschau 7: 215-216.

9th Int Thyroid Congr (1985): São Paulo: Program and Abstract: 78-84, 109-112.

Olbricht T, Schmitka T, Mellinghoff U, Benker G \& Reinwein D (1982): Sonographische Bestimmung von Schilddrüsenvolumina bei Schilddrüsengesunden. Dtsch Med Wochenschr 108: 1355- 1358.

Pezzino V, Vigneri R, Squatrito S, Filetti S, Camus M \& Polosa P (1978): Increased serum thyroglobin levels in patients with nontoxic goiter. J Clin Endocrinol Metab 46: 653-657.

Pickardt C R, Erhardt F, Grüner J, Horn K \& Scriba P C (1972): Stimulation der TSH-Sekretion durch TRH bei blander Struma: Diagnostische Bedeutung und pathophysiologische Folgerung. Klin Wochenschr 50: 1134-1137.

Schoknecht G \& Barich G (1975): Bestimmung der Häufigkeitsverteilung von Strumen mit Röntgenschirmbildaufnahmen bei Filteruntersuchungen. Dtsch Med Wochenschr 100: 1860- 1862.

Stubbe P \& Heidemann P (1983): Struma neonatorum - blande Struma im Kindesalter. Dtsch Ärzteb 80: 40-42.

Wawschinek O, Eber O, Petek W, Wakonig P, Gürakar A (1985): Bestimmung der Harnjodausscheidung mittels einer modifizierten Cer-Arsenitmethode. Ber ÖGKC 8: 13-15.

Wood W G, Waller D E \& Hantke U (1985): Eine objektive Beurteilung sechs kommerzieller Testbestecke zur Bestimmung von Thyrotropin. J Clin Chem Clin Biochem 23: 461-471.

Received December 2nd, 1985.

Accepted February 17th, 1986. 